Marquette University

e-Publications@Marquette

3-1-2015

\title{
Medicaid Expansions for the Working Age Disabled: Revisiting the Crowd-out of Private Health Insurance
}

Kathryn L. Wagner

Marquette University, kathryn.l.wagner@marquette.edu

NOTICE: this is the author's version of a work that was accepted for publication in Journal of Health Economics. Changes resulting from the publishing process, such as peer review, editing, corrections, structural formatting, and other quality control mechanisms may not be reflected in this document. Changes may have been made to this work since it was submitted for publication. A definitive version was subsequently published in Journal of Health Economics, Vol. 40 (March 2015): 69-82. DOI. (C) 2015 Elsevier. Used with permission.

Kathryn L. Wagner was affiliated with University of Notre Dame at the time of publication. 


\title{
Medicaid Expansions for the Working Age Disabled: Revisiting the Crowd-out of Private Health Insurance
}

\author{
Kathryn L. Wagner \\ Department of Economics, Marquette University \\ Milwaukee, WI
}

\begin{abstract}
:
Disabled individuals under 65 years old account for $15 \%$ of Medicaid recipients but half of all Medicaid spending. Despite their large cost, few studies have investigated the effects of Medicaid expansions for disabled individuals on insurance coverage and crowd-out of private insurance. Using an eligibility expansion that allowed states to provide Medicaid to disabled individuals with incomes less than $100 \%$ of the federal poverty level, I address these issues. Crowd-out estimates range from 49\% using an ordinary least squares procedure to $100 \%$ using two-stage least- squares analysis. This potentially large degree of crowd-out could have fiscal implications for the Affordable Care Act which has greatly expanded Medicaid eligibility in 2014.
\end{abstract}

Keywords: Medicaid Expansions, Health Insurance, Crowd-out, Disability. (JEL: H4, I1)

\section{Introduction}

A major feature of the healthcare reform enacted in the United States under the Patient Protection and Affordable Care Act (PPACA) is the expansion of state Medicaid programs to provide health coverage to all individuals under the age of 65 who have incomes less than $138 \%$ of the Federal Poverty Level (FPL). As of November 2014, only 
27 states have expanded their Medicaid programs, but estimates suggest that more than 25 million uninsured Americans would gain coverage if all states were to adopt the legislation (Kaiser Family Foundation, 2012, 2014, Holahan et al., 2012). ${ }^{1}$ A widespread concern of expanding Medicaid is that newly eligible individuals who have private insurance will choose to drop their private plans and take-up Medicaid coverage instead due to Medicaid's low cost - a phenomenon known as "crowd-out." The Urban Institute's Health Insurance Policy Simulation Model (HIPSM) assumes a crowd-out rate of $22 \%$ to predict changes in insurance coverage from the PPACA (Buettgens, 2011). This rate is primarily based on crowd-out estimates from Medicaid expansions for children and their parents. Children and parents are expected to make up a small portion of the new Medicaid eligibles, however, under the PPACA. If crowd-out for other populations is larger than $22 \%$, then the predictions from HIPSM will overestimate the reduction in the uninsured population from the PPACA Medicaid expansions (Holahan et al., 2012).

One subset of the population that stands to gain from the PPACA Medicaid expansions is disabled individuals under 65. Medicaid has typically only covered disabled individuals with very low income levels, but the PPACA will allow those with higher levels of income to qualify. The average income eligibility limit for the disabled was $87 \%$ of the federal poverty level (FPL) in 2008. More than 3.5 million work disabled Americans had incomes between 87 and 138\% FPL in 2011 (Author's calculations using the March CPS 2012) and would be eligible for coverage if all states adopt the PPACA Medicaid expansions.

The disabled under 65 are the most expensive coverage group under Medicaid and accounted for $43 \%$ ( $\$ 160$ billion) of total Medicaid payments even though they made up only 15\% of recipients in 2009 (Kaiser Family Foundation: statehealthfacts.org). Despite their expense, effects from Medicaid eligibility expansions for the disabled population are not well understood. This paper examines a Medicaid eligibility expansion that allowed states the option to offer Medicaid to their disabled residents who had monthly incomes up to $100 \%$ of the FPL. Given their different health needs and cost of care, the disabled

\footnotetext{
${ }^{1}$ Initially, the PPACA Medicaid expansions were required of all states, but became optional under a June 2012 Supreme Court ruling.
}

Journal of Health Economics, Vol. 40 (March 2015): pg. 69-82. DOI. This article is @ Elsevier and permission has been granted for this version to appear in e-Publications@Marquette. Elsevier does not grant permission for this article to be further copied/distributed or hosted elsewhere without the express permission from Elsevier. 
population may experience a different rate of crowd-out than children and parents.

In this paper, I focus on the effects of Medicaid eligibility on health coverage for working-age individuals who report having a work disability. As with earlier Medicaid expansion research, OLS estimates are subject to omitted variables bias and measurement error. To account for these issues, I use the simulated instrument originally described in Currie and Gruber (1996a and 1996b) to measure only the legislative effect of changes in Medicaid eligibility. Using two large, nationally representative datasets and a two-stage least-squares (2SLS) analysis, I find the rate of crowd-out to be about $100 \%$. This rate is much larger than what has been found in Medicaid expansions for parents and children. The point estimate of crowd-out is statistically significant at the $5 \%$ level and is robust to several alternative samples. The confidence interval for this estimate, however, is broad and so we interpret it with caution.

\section{Literature Review}

Simon and Gruber (2008) provide an excellent review of the crowd-out literature which I will briefly summarize below. The effect of Medicaid eligibility expansions on participation and crowd-out has been primarily investigated through expansions for children and their families. The flagship paper in this field is Cutler and Gruber (1996) who used a 2SLS approach to investigate the effect of Medicaid eligibility expansions for children and pregnant women on health insurance coverage with the simulated eligibility instrument of Currie and Gruber (1996a, 1996b). Cutler and Gruber (1996) found a large and statistically significant degree of crowd-out, but many follow-up papers found smaller amounts. Across the entire literature, crowd-out measures have varied widely from as small as $0 \%$ to as large as $60 \%$ for children and families. ${ }^{2}$

\footnotetext{
2 See Aizer and Grogger (2003), Blumberg et al. (2000), Card and Shore-Sheppard (2004), Cutler and Gruber (1996), Dubay and Kenney (1996) and (1997), Gruber and Simon (2008), Ham and Shore-Sheppard (2005), Hamersma and Kim (2013), Hudson et al. (2005), LoSasso and Buchmueller (2004), Shore-Sheppard (2008), Thorpe and Florence (1998), and Yazici and Kaestner (2000) for these estimates.
}

Journal of Health Economics, Vol. 40 (March 2015): pg. 69-82. DOI. This article is (C) Elsevier and permission has been granted for this version to appear in e-Publications@Marquette. Elsevier does not grant permission for this article to be further copied/distributed or hosted elsewhere without the express permission from Elsevier. 
Subsequent papers explain the smaller size of crowd-out through several key criticisms of the Cutler and Gruber (1996) empirical strategy, one of which is that they used the annual from the March Current Population Survey (CPS) rather than monthly data from the Survey of Income and Program Participation (SIPP). In this paper, I analyze data from both the CPS and the SIPP and find similar results for the disabled population. Another critique in this literature is that crowd-out estimates can be sensitive to the treatment of individuals reporting private and Medicaid coverage simultaneously (Gruber and Simon, 2008). Populations with overlapping coverage can be interpreted in multiple ways, but it has become standard practice to assume that this group is transitioning from private insurance to Medicaid. In my analysis, I find little difference in crowd-out measures accounting and not accounting for the overlap population.

In addition to crowd-out for children and parents, a recent paper finds evidence of crowd- out among the childless adult population. Garthwaite et al. (2013) finds that private health insurance coverage sharply increased for childless adults in conjunction with an increase in their labor supply after their disenrollment from TennCare, an extension of Tennessee's Medicaid program. This implies that childless adults pursued health coverage through an employer after losing public coverage and this suggests evidence of crowd-out. ${ }^{3}$ The results from Garthwaite et al. (2013) are informative regarding the PPACA Medicaid expansions since the majority of those who will become eligible are childless adults. Disabled individuals, though they make up a smaller portion of the PPACA eligible population, will gain some eligibility through the expansions. Given their expensive health care needs, the cost of the PPACA expansions for disabled individuals may be economically meaningful despite their small population size.

\section{Medicaid, Eligibility Expansions, and Eligibility Pathways for the Disabled}

In fiscal year 2010, Medicaid spent $\$ 389$ billion to provide health coverage to roughly 60 million low-income Americans (Kaiser Family

\footnotetext{
${ }^{3}$ It should be noted, however, that the results for the TennCare disenrollment are unique in the literature and several other papers (in particular those on the Oregon Health Insurance Experiment) do not find big changes in employment due to health insurance (Baicker et al., 2013).
}

Journal of Health Economics, Vol. 40 (March 2015): pg. 69-82. DOI. This article is @ Elsevier and permission has been granted for this version to appear in e-Publications@Marquette. Elsevier does not grant permission for this article to be further copied/distributed or hosted elsewhere without the express permission from Elsevier. 
Foundation: statehealthfacts.org). The program is means-tested and jointly funded by both federal and state governments with the federal government covering at least half of all Medicaid spending for each state (Kaiser Family Foundation: statehealthfacts.org). ${ }^{4}$ States are responsible for the administration of their own Medicaid programs, but are required to meet minimum federal requirements in terms of services covered and eligibility standards. While Medicaid also covers groups such as children, pregnant women, parents, and the elderly, I will focus on the coverage of disabled individuals.

There are several pathways through which disabled people can become eligible for Medicaid coverage. I impute eligibility based only on three pathways where an individual qualifies for coverage by having low income and a disability: the Supplemental Security Income Program (SSI), the State Supplemental Payment Program (SSP), and poverty-related coverage. SSI and SSP are programs that provide cash assistance to disabled individuals and typically come with Medicaid coverage automatically. ${ }^{5}$ These pathways are accounted for when imputing eligibility, but there were few changes in the eligibility standards for these programs from 1995 to 2007 and they do not provide much variation.

Of the three main eligibility pathways used to impute eligibility in this paper, poverty- related Medicaid has experienced the greatest changes recently and generates most of the variation that identifies the econometric model. The Omnibus Reconciliation Act of 1986 (OBRA86) authorized this pathway and gave states the option to increase the Medicaid income eligibility level for the disabled up to $100 \%$ of the federal poverty level (FPL). Prior to the OBRA86, disabled individuals mainly had to qualify under SSI which required an income level below 74\% FPL of income (Social Security Administration, 2012). While some states opted into the $100 \%$ FPL pathway soon after the

\footnotetext{
${ }^{4}$ The federal reimbursement rate of Medicaid expenses in each state is called the Federal Medical Assistance percent (FMAP). FMAPs range from $50 \%$ to $74.73 \%$. States with lower incomes per capita relative to the US income per capita receive higher reimbursement rates from the federal government (Baumrucker, 2010).

${ }^{5}$ This is not always the case. 209(b) states are allowed to have stricter standards for eligibility than SSI standards. Some states also require a separate application for Medicaid in addition to their SSI application.
}

Journal of Health Economics, Vol. 40 (March 2015): pg. 69-82. DOI. This article is @ Elsevier and permission has been granted for this version to appear in e-Publications@Marquette. Elsevier does not grant permission for this article to be further copied/distributed or hosted elsewhere without the express permission from Elsevier. 
NOT THE PUBLISHED VERSION; this is the author's final, peer-reviewed manuscript. The published version may be accessed by following the link in the citation at the bottom of the page.

passage of the OBRA86, after this initial round of adoptions, eight states increased the income eligibility level for the disabled to $100 \%$ of the FPL between 1998 to 2003 period (Bruen et al., 2003). I take advantage of the variation in timing of adopting the poverty-related coverage as well as the magnitude of the income eligibility level during this later enactment period to identify changes in Medicaid take-up and crowd-out.

There are other pathways for disabled Medicaid eligibility that are not used for eligibility imputation in this analysis. One such pathway is a Medically Needy program through which some states provide Medicaid to disabled individuals with exorbitant medical fees. Another pathway is a state buy-in program that allows disabled individuals with incomes above the eligibility levels to purchase Medicaid as an insurance plan. Buy-in plans required that purchasers be employed and pay a premium for coverage which is unlike the three pathways used to impute eligibility. To ensure that buy-in programs are not what drives my results, I run an additional model that adds buy-in program indicator variables to the main model. ${ }^{6}$

The final pathway excluded from eligibility imputation is cost sharing options with Medicare or dual-eligibles (see the appendix for more information on these individuals). The benefits package for dualeligibles is not as generous as the package received under other pathways of eligibility. As a result I treat individuals who qualify for Medicaid coverage under cost sharing as having an alternative form of Medicaid and Medicaid participation results in this paper do not consider Medicare cost sharing recipients. ${ }^{7}$ See the Appendix for further information on Medicaid eligibility pathways for the disabled.

\footnotetext{
${ }^{6}$ With the addition of controls for the presence of a Buy-in program the estimates of take-up for Medicaid and private insurance is $0.404(0.140)$ and $-0.445(0.148)$ respectively. The coefficients on the Buy-in indicator variable in these models are $-0.002(0.011)$ and $0.009(0.015)$ suggesting that the presence of a buy-in program had little effect on the Medicaid and Private insurance take-up rates. State clustered standard errors are in parentheses.

${ }^{7}$ Including cost sharing individuals in the analysis produces Medicaid and private take-up estimates of $0.339(0.180)$ and $-0.529(0.213)$ respectively. Standard errors are in parentheses. These estimates suggest a crowd-out point estimate of $156 \%$ which is even larger than the primary specification.
}

Journal of Health Economics, Vol. 40 (March 2015): pg. 69-82. DOI. This article is (C) Elsevier and permission has been granted for this version to appear in e-Publications@Marquette. Elsevier does not grant permission for this article to be further copied/distributed or hosted elsewhere without the express permission from Elsevier. 


\section{Data and Methodology}

Following the approach from Cutler and Gruber (1996) for measuring the impact of Medicaid expansions on take-up and crowdout, we estimate the following equation

$$
\text { Coverage }_{i s t}=\alpha+\text { Eligible }_{i s t} \beta_{1}+X_{i s t} \beta_{2}+\gamma_{s}+\delta_{t}+\varepsilon_{i s t}
$$

where $i, s$, and, $t$ index the individual, state, and year respectively. The dependent variable, Coverage ist, $_{\text {, }}$ is an indicator variable that equals 1 if an individual has health coverage of a certain type (Medicaid, Private, or Uninsured), and equals zero otherwise. The key variable of interest, Eligible ist, $_{\text {, }}$ is an indicator variable that equals 1 if a person is eligible for Medicaid coverage and zero otherwise. $X_{i s t}$ is a vector of demographic characteristics including age, education, sex, race, family size, number of children in the household, and marital status. The variables $\gamma_{s}$ and $\delta_{t}$ are state and year fixed effects respectively and the final term is a random error.

In order to impute eligibility, we must first determine the Medicaid standards specific to each state and year. There is no central database for state Medicaid eligibility policies. Following Brown et al. (2007) and Coe (2005), I compiled Medicaid eligibility information from numerous sources. ${ }^{8}$ With this information, I constructed the income eligibility limits for disabled Medicaid applicants in each state for all years between 1996 and 2007. The income eligibility limit is the highest level of income (as a percent of the federal poverty level) that a disabled individual can have and still qualify for Medicaid coverage. This is constructed by taking the most generous of the SSI/209(b), povertyrelated, and SSP pathways available to the disabled in a given state and year. The 1996 and 2007 income eligibility limits by state are shown in Table 1.

Using the eligibility standards for each state, we can impute eligibility for an individual. To do this we use the 1996, 2001, and 2004 panels of the Survey of Income and Program Participation

\footnotetext{
${ }^{8}$ The specific sources used to construct the upper income threshold of Medicaid eligibility rules for the aged and disabled were Brown et al. (2005) , Bruen, Wiener, and Thomas (2003), Bruen, Wiener, Kim, and Miazad (1999), Coe (2005) , Congressional Research Service (1993), De Nardi et al. (2011), Horvath (1997), Kaiser Commission on Medicaid and the Uninsured (2010), Kassner (2000), Mississippi Division of Medicaid (1991-2008), Social Security Administration (1991-2008), Stone $(2002,2011)$, and state Medicaid websites.
}

Journal of Health Economics, Vol. 40 (March 2015): pg. 69-82. DOI. This article is @ Elsevier and permission has been granted for this version to appear in e-Publications@Marquette. Elsevier does not grant permission for this article to be further copied/distributed or hosted elsewhere without the express permission from Elsevier. 
(SIPP). Each SIPP panel has 12 waves (interviews) except the 2001 panel which only has nine and surveys at least 40,000 households. Every four months, the SIPP asks respondents a set of core questions including information on basic demographics (age, sex, race, etc.), income, and participation in programs such as Medicaid or Supplemental Security Income. Respondents are interviewed every four months, but are asked to report information for each of the four months in the reference period. Thus the core data in the SIPP are at the person-month level. ${ }^{9}$ I limit the analysis, however, to only observations reported in the fourth reference month due to the potential for transitions in health coverage or family status only being reported between interviews ("seams") rather than between months. This is consistent with other work on Medicaid using the SIPP (Hamersma and Kim, 2013; Gruber and Simon, 2008).

\subsection{Definition of Disability}

The official definition of disability for Medicaid eligibility is the same definition the Social Security Administration (SSA) employs for SSI qualification (Families USA, 2001). This definition also applies for the higher income individuals qualifying under the OBRA86 Medicaid expansions. Per SSA guidelines an adult is disabled if she has a "medically determinable physical or mental impairment" that prevents "substantial gainful activity" and is expected to "result in death" or has "lasted or can be expected to last for a continuous period of not less than 12 months" (Social Security Administration, 2012). This is a broad definition that relies heavily on a doctor's subjective opinion as to the severity of the condition rather than a decisive cutoff measurement. Household surveys do not contain a measure of this exact definition and more often contain information regarding different difficulties or specific conditions of an individual.

\footnotetext{
${ }^{9}$ Given that the SIPP is a panel data set it is possible that a respondent could have up to 12 interviews in any given pattern. Standard errors throughout the main analysis are clustered at the state level since the Medicaid expansions vary by the state. When we cluster at the individual level, however, the standard errors are similar. The individually clustered standard errors for Medicaid, Private, and Overlap take-up estimates are (0.147), (0.160), and (0.063) respectively.
}

Journal of Health Economics, Vol. 40 (March 2015): pg. 69-82. DOI. This article is @ Elsevier and permission has been granted for this version to appear in e-Publications@Marquette. Elsevier does not grant permission for this article to be further copied/distributed or hosted elsewhere without the express permission from Elsevier. 
The closest measure of disability that is available in both the SIPP and March CPS are the work disability variables in those surveys. ${ }^{10}$ These certainly have their limitations in that they are self-reported in both surveys and individuals may not have a clear conception of disability or impairment status when answering the question (US Census Bureau, 2012). Despite these limitations, however, there is some evidence to document that disability trends in work disability status may be related to disability trends measured by impairment status. This suggests that though the work disability measure is not perfect it is correlated with other conceptualizations of disability (Burkhauser et al., 2003).

Within the SIPP, $85 \%$ of individuals aged $20-64$ who report having a work disability have a total personal income less than the average per capita income in the United States and $65 \%$ of these individuals have incomes less than half the average per capita income. Since "substantial gainful activity" for disability is commonly measured in terms of an income cutoff, the work disabled sample appears to be identifying a population that may have difficulties performing substantial gainful activity. Measurement error for this disability definition also does not appear to be related to the Medicaid legislative changes as individuals were not more likely to report a work disability after the eligibility expansions went into effect (results not shown).

\subsection{Imputing Eligibility}

A person is eligible for Medicaid coverage if her personal income minus income disregarded from eligibility determination is less than the threshold in a person's state of residence. Eligibility is defined as a person's own eligibility. ${ }^{11}$ Income considered during eligibility

\footnotetext{
${ }^{10}$ The specific question from the SIPP survey is "Does ... have a physical, mental, or other health condition that limits the kind or amount of work ... can do at a job or business?" (United States Census Bureau, 1996). The specific question in the March CPS is "(Do you/Does anyone in this household) have a health problem or disability which prevents (you/them) from working or which limits the kind or amount of work (you/they) can do?" (United States Census Bureau, 2012).

${ }^{11}$ Gruber and Simon (2008) demonstrated the sensitivity of results to family spillover effects where a child could benefit from a sibling being Medicaid eligible. Since the sample I am considering includes working-age disabled adults rather than children and one individual's Medicaid status does not influence another's, I do not use family income to determine eligibility. I do, however, run an analysis where I include spousal income in eligibility determination. In this
} 
NOT THE PUBLISHED VERSION; this is the author's final, peer-reviewed manuscript. The published version may be accessed by following the link in the citation at the bottom of the page.

determination is referred to as countable income and is constructed by subtracting disregards - any income that is not considered when determining Medicaid eligibility - from a person's total income. There are several types of income that are disregarded from Medicaid eligibility determination. By federal law, every individual receives an automatic monthly disregard of $\$ 20$. Some states (such as California and Connecticut) choose to disregard larger amounts. Also, income received through the Supplemental Security Income program does not count towards Medicaid eligibility. ${ }^{12}$ In addition to SSI payments, a portion of earned income is disregarded. ${ }^{13}$ Subtracting the total amount of disregards from an individual's total income produces countable income for Medicaid eligibility. ${ }^{14}$

In reality, Medicaid eligibility is determined not only using a person's income level but also her financial assets. The SIPP, however, only contains asset information once a year rather than a monthly basis like income information. Due to this restriction, my main analysis does not consider assets when determining eligibility. ${ }^{15}$ This is a

analysis, a couple is eligible for Medicaid if at least one of them reports having a work disability and the total income from both individuals is less than the Federal Poverty Level for a family of size 2 . The crowd-out measurements from the spousal analysis are not substantially different from the individual eligibility analysis. Spousal analysis Medicaid, Private, and Overlap take-up rates are $0.445(0.187),-0.532(0.152)$, and $0.031(0.094)$ respectively. State clustered standard errors are in parentheses.

12 In the majority of states, a recipient of Supplemental Security Income is automatically eligible for Medicaid coverage. In 2008, however, there were eleven states that used the 209(b) option which allowed state Medicaid offices to impose stricter standards on Medicaid eligibility than federal SSI requirements.

${ }^{13} \$ 65$ plus $1 / 2 *$ (total income earned -65 ) per month of earned income is not counted towards eligibility determination.

${ }^{14}$ Given that the income information in the SIPP is self-reported, there is likely measurement error in the imputed eligibility variable. Hamersma and Kim (2013) proposed an estimation strategy in which we use the actual Medicaid income threshold (as a percent of the FPL) rather than imputed eligibility. Following this strategy, I find the effect on Medicaid, Private, and Overlap insurance to be $0.133(0.050),-0.150(0.080)$, and $0.043(0.019)$ respectively. State clustered standard errors are in parentheses. The Hamersma and Kim strategy take-up rates suggest similar point estimates as my primary analysis, but only crowd-out estimates accounting for the overlap group are statistically significant at the $5 \%$ level.

${ }^{15}$ In an annual analysis, using asset information to determine eligibility does not greatly influence results.

Journal of Health Economics, Vol. 40 (March 2015): pg. 69-82. DOI. This article is @ Elsevier and permission has been granted for this version to appear in e-Publications@Marquette. Elsevier does not grant permission for this article to be further copied/distributed or hosted elsewhere without the express permission from Elsevier. 
restriction that most papers on crowd-out face and assets usually have not been used in the imputation of eligibility. The SIPP does not uniquely identify every state and instead groups some states together in some of its panels. As a result, I drop five states from the analysis (Maine, North Dakota, South Dakota, Vermont, and Wyoming).

Given the research question, I limit the sample to respondents within the SIPP who report a work-limiting disability. I eliminate everyone under the age of 20 (who could potentially qualify for Medicaid under eligibility rules for children which are more generous) and the elderly (those over the age of 65 , most of who automatically qualify for Medicare). Across all three panels of the SIPP considered in this study, 41,554 individuals between 20 and 64 years of age reported having a work-limiting disability. In 1996, the first year of our sample, 819 individuals reported a work-limiting disability and had incomes between 74 and $100 \%$ of the FPL and was approximately $1.5 \%$ of the working age population in that year. Of these 819 individuals, $37 \%$ resided in a state that would eventually expand Medicaid to the disabled using the OBRA86 option.

Summary statistics for the ineligible and the eligible sample in the SIPP are presented in Table 2 . The observed differences between the two samples are consistent with previous research. The eligible sample contains a higher percentage of women, blacks, and those individuals with lower levels of education which is not surprising as these characteristics are associated with lower income levels and disadvantaged populations. As expected, there is a dramatic difference in income between the ineligible and the eligible samples since this is a key determinant of eligibility. The eligible group also has higher rates of Medicaid coverage and uninsurance and are less likely to have private plans or be on Medicare.

Since the OBRA86 expansions raised Medicaid eligibility levels above SSI qualification levels, the majority of Medicaid take-up and crowd-out will be driven by non-SSI recipients. Disabled individuals through SSI, however, may be inherently different from non-SSI individuals perhaps due to various health conditions or income levels. Non-SSI Medicaid recipients, however, constitute a large share of the disabled Medicaid population. Nearly $40 \%$ of disabled Medicaid enrollment was for non-SSI beneficiaries in 2010 (statehealthfacts.org). This is consistent with summary statistics in the granted for this version to appear in e-Publications@Marquette. Elsevier does not grant permission for this article to be further copied/distributed or hosted elsewhere without the express permission from Elsevier. 
SIPP which had $42 \%$ of work disabled individuals possessing Medicaid coverage but not receiving income from SSI. Thus, though the majority of disabled Medicaid beneficiaries originate from the SSI program, there is also a fairly large number of non-SSI Medicaid beneficiaries. Given the size of their population and since the majority of future Medicaid income-eligibility expansions will apply to them, take-up and crowd-out rates for the non-SSI disabled are relevant even if they are inherently different from SSI recipients.

OLS estimates of equation (1) are potentially subject to an omitted variables bias. Characteristics that determine eligibility for Medicaid are likely linked with demand for health insurance. Though many of these characteristics are accounted for in the demographic controls vector, there may be omitted variables influencing insurance take-up. Reverse causality may also be a concern within the model. Given that I am examining a sample of individuals reporting a disability, it is likely that many of them face difficulties working. Since a large share of private health coverage is provided through employers, a large portion of my sample may be less likely to have private coverage due to an inability to work which also results in lower levels of income. Thus, there is a potential for a negative spurious relationship between Medicaid eligibility and health coverage. Since Medicaid eligibility is also imputed using reported income information from the SIPP, measurement error is likely present in the model as well.

To account for the omitted variables bias, measurement error, and reverse causality concerns, I follow Currie and Gruber (1996a and 1996b) and construct a simulated instrument for eligibility. Since my sample size is small and not computationally overwhelming, I use the entire sample of disabled respondents from each year to simulate the instrument rather than select a smaller random sample as has been done in previous work. Using this national population, the simulated instrument is constructed as the percent of people that would be eligible for Medicaid coverage under each state's individual eligibility rules for each year. When constructing these shares, I exclude respondents from the state whose laws are being used to simulate eligibility (Ham and Shore-Sheppard, 2005). These percents are then matched by state and year (based on the eligibility rules that constructed them) to respondents in the sample.

Journal of Health Economics, Vol. 40 (March 2015): pg. 69-82. DOI. This article is @ Elsevier and permission has been granted for this version to appear in e-Publications@Marquette. Elsevier does not grant permission for this article to be further copied/distributed or hosted elsewhere without the express permission from Elsevier. 
NOT THE PUBLISHED VERSION; this is the author's final, peer-reviewed manuscript. The published version may be accessed by following the link in the citation at the bottom of the page.

By constructing the simulated instrument, we are effectively producing a measure of Medicaid generosity by state and year that is not dependent upon the characteristics of the population within a given state. Instead, the variation in eligibility across state and time reflects the legislative changes in eligibility rules. Thus, the instrument depends on changes in state legislation concerning eligibility being exogenous. Essentially, we want it to be the case that OBRA86 adopting states did not experience different trends in coverage rates compared to non- adopting states prior to the expansions. In Table 3, using data from the March CPS, I test the difference between pretrends and post-trends for adopting and non-adopting states. I use data from the CPS rather than the SIPP because it allows us to observe a longer period prior to the start of expansions. The data is collapsed to construct the rate of coverage for the four forms of insurance by state and year. These rates are then regressed on state and year fixed effects and two variables that measure the pre- and post-adoption trends for states. The pre-adoption trend variable is a negative integer value that indicates the number of years until an expanding state's adoption or zero for non-adopting states and years after the expansion. The post-adoption trend variable is a positive integer value that indicates the number of years after an expanding state's adoption or zero for non-adopting states and years prior to the expansion.

Table 3 presents the regression results for the pre-treatment analysis. There is no statistically significant difference in the preadoption trends of coverage rates between adopting and non-adopting states for any of the insurance types and the coefficients are all near zero. This implies that states experienced little difference in coverage rate trends leading up to the expansions. The post-adoption trends for Medicaid and private coverage, however, are statistically significantly different between adopting and non-adopting states (see Columns 1 and 2 in Table 3). Adopting states experienced an increase in their Medicaid coverage rates and a decrease in their private insurance rates relative to non-adopting states after the eligibility expansions went into effect. The post-adoption coverage trends for Medicare and uninsurance are not statistically significantly different between the two types of states. These results are indicative of crowd-out though the magnitudes of the coefficients in this analysis do not suggest that crowd-out was complete. Overall, the results contained in Table 3 indicate that pre-adoption coverage rate trends were similar for

Journal of Health Economics, Vol. 40 (March 2015): pg. 69-82. DOI. This article is @ Elsevier and permission has been granted for this version to appear in e-Publications@Marquette. Elsevier does not grant permission for this article to be further copied/distributed or hosted elsewhere without the express permission from Elsevier. 
adopting and non-adopting states and support the validity of the instrument, but by no means are a sufficient condition for no endogeneity.

\section{Results}

\subsection{Tabular Results}

Following earlier literature, we first construct difference-indifference measures of crowd-out using a tabular approach. The top section of Table 4 contains the changes in health insurance coverage from 1996 (the beginning of our sample) to 2007 (the end of our sample) across four income groups using the work disability sample of the SIPP. In order to demonstrate the sensitivity of our crowd-out results to individuals who report possessing both private and Medicaid insurance coverage at the same time, we define three forms of health coverage: Medicaid only, private only, and overlapping coverage (Gruber and Simon, 2008). ${ }^{16}$ In addition to changes in health coverage, Table 4 also reports changes in imputed eligibility for each income group. Standard errors are in parentheses and are clustered at the state level.

Given that the OBRA86 expansions effectively raised the income thresholds for Medicaid eligibility from 74 to $100 \%$ of the FPL, we expect individuals with countable incomes within this range to be the most affected by the expansion. Table 4 suggests that this is the case. The lower section of Table 4 reports difference-in-difference estimates of eligibility and health coverage from the $74-100 \%$ FPL income group relative to three other income categories (less than $74 \% \mathrm{FPL}$, between $100-150 \% \mathrm{FPL}$, and greater than $150 \% \mathrm{FPL})$. Table 4 also compares the $74-100 \%$ FPL group to all three of these other groups combined. Imputed Medicaid eligibility for the 74 to $100 \%$ FPL group increased by about 20 percentage points relative to every other income group from 1996 to 2007 . The rate of eligibility remained virtually unchanged for the other income groups across the time period. Coverage by Medicaid displays a similar pattern as eligibility. Relative to the other income

${ }^{16}$ Coverage definitions for the tabulation results only take into account various forms of private and Medicaid coverage. Individuals may have alternative forms of coverage (such as military insurance or Medicare), but these are not accounted for in the coverage definitions for this analysis. These alternative forms are considered in a later robustness analysis.

Journal of Health Economics, Vol. 40 (March 2015): pg. 69-82. DOI. This article is @ Elsevier and permission has been granted for this version to appear in e-Publications@Marquette. Elsevier does not grant permission for this article to be further copied/distributed or hosted elsewhere without the express permission from Elsevier. 
groups, Medicaid coverage increased between 9.0 to 12.4 percentage points for the $74-100 \%$ FPL income group and 10.4 percentage points relative to all other income groups combined. All income groups experienced a reduction in private coverage over the time period, but the largest decrease was for the 74 to $100 \%$ FPL group. The change in overlap coverage is similar across all income groups.

Table 5 presents crowd-out measures resulting from the tabular results in Table 4. Following Gruber and Simon (2008), we construct one measure of crowd-out that ignores the overlap group and another measure of crowd-out which interprets the overlap coverage as a transition from private to Medicaid coverage. Table 5 presents crowdout estimates ranging from 16 to $80 \%$ that appear to be insensitive to the treatment of the overlap group. Standard errors are in parentheses and are calculated from the difference-in-difference estimates using the delta method. Relative to all of the other income groups combined, the rate of crowd-out was between 54 to $60 \%$ which is consistent with the crowd-out estimates in the children's Medicaid expansions (Gruber and Simon, 2008). The 95\% confidence intervals for these estimates allow us to rule out a crowd-out rate below $29 \%$ and above $85 \%$.

OLS estimates are consistent with the range of crowd-out levels implied by the Diff-in- Diff tabulation estimates though slightly smaller. Crowd-out measures from OLS estimates are between 49 to $53 \%$ (see results in Table 6). Though the tabulation and OLS estimates provide us with a general idea of changes in coverage and crowd-out, they are likely to be biased and we proceed accordingly with an instrumental variables analysis.

\subsection{Two-Stage Least-Squares Estimates}

Table 7 presents 2SLS estimates that correspond to Equation 1. The key covariate in these models is the variable, Eligible, the indicator variable for whether an individual is imputed to be eligible for Medicaid, is the dependent variable in these regressions. We instrument for this with the simulated eligibility variable and the firststage estimates are reported in column (1). All models include state, year, and SIPP panel-wave fixed effects, age, age squared, female sex, black race, Hispanic origin, marital status, less than high school education, high school diploma, a cubic in income, and a state-year

Journal of Health Economics, Vol. 40 (March 2015): pg. 69-82. DOI. This article is @ Elsevier and permission has been granted for this version to appear in e-Publications@Marquette. Elsevier does not grant permission for this article to be further copied/distributed or hosted elsewhere without the express permission from Elsevier. 
linear trend as additional controls. ${ }^{17}$ Standard errors allow for arbitrary correlation in errors within a state. It is no surprise that simulated eligibility and imputed eligibility are positively correlated. Indeed, firststage estimates in column (1) suggest a large positive effect on the likelihood of being Medicaid eligible with more generous Medicaid programs (as measured by the simulated instrument). First-stage estimates indicate that for a 10 percentage point increase in simulated eligibility, there will be a 7.32 percentage point increase in actual eligibility. The coefficient on the instrument is statistically significant at the $1 \%$ level and the F-statistic for the null of the coefficient on the instrument is 24 .

The final four columns of Table 7 presents 2SLS estimates from the SIPP for various forms of insurance coverage using simulated Medicaid eligibility as an instrument for Medicaid eligibility. We consider the effects of Medicaid eligibility on the same forms of coverage as in the tabulation analysis and also on whether an individual is uninsured. ${ }^{18}$ The effects on Medicaid only, private only, and overlap coverage do not need to sum to the effect on the uninsured due to potential joint coverage under Medicare or military insurance. We explore these possibilities in a robustness check later in the paper.

The key variable of interest is Eligible, which measures the effects of Medicaid eligibility on the four forms of coverage. Column (2) of Table 7 presents the results for Medicaid only participation. Results suggest a $41 \%$ take-up rate for Medicaid after the eligibility expansions. This means that for every 100 individuals made eligible through the expansion, 41 chose to take up Medicaid coverage. In conjunction with this increase in Medicaid coverage, there is a roughly equivalent decrease in private coverage. Estimates suggest that 45 individuals lose private coverage for every one hundred who become eligible for Medicaid. Coverage for the overlap group increases by 0.15 percentage points for every ten percentage point increase in Medicaid eligibility but is statistically insignificant. Including the effects from the

${ }^{17}$ SIPP panel-wave fixed effects were included in the regressions to account for differences in interview structures. Excluding these fixed effects does not greatly affect the results.

${ }^{18}$ We define a respondent to be uninsured if she reports no coverage from Medicaid, private, military, or Medicare insurance.

Journal of Health Economics, Vol. 40 (March 2015): pg. 69-82. DOI. This article is @ Elsevier and permission has been granted for this version to appear in e-Publications@Marquette. Elsevier does not grant permission for this article to be further copied/distributed or hosted elsewhere without the express permission from Elsevier. 
overlap group implies a Medicaid take-up rate of $42 \%$ and a private coverage reduction rate of $46.5 \%$. The rate of uninsurance increases by 1.11 percentage points for every ten percentage point increase in Medicaid eligibility though this result is not statistically significant.

Table 8 presents the crowd-out estimates implied by the take-up rates in Table 7 . For the purposes of this paper, we define crowd-out to be the change in private insurance coverage relative to the change in Medicaid coverage. ${ }^{19}$ The results in the No Overlap column (1) ignores any effects from the overlap group while the Overlap column (2) accounts for the overlap group by assuming its effect represents a transition from private insurance to Medicaid. Crowd-out measures appear to be insensitive to the treatment of the overlap group. The SIPP estimates suggest complete crowd-out between 110 to $111 \%$. Measures of crowd-out are statistically significant at the $5 \%$ level for both the overlap and no overlap groups using bootstrapped confidence intervals. ${ }^{20}$ The confidence intervals allow us to reject the hypothesis that crowd-out was equal to zero at a $5 \%$ level in the SIPP and also allow us to reject crowd-out rates lower than $26 \%$ and higher than $390 \%$. Given that the $95 \%$ confidence intervals suggest a broad range of crowd-out estimates, we need to interpret the crowd-out point estimate with caution. The intervals do suggest, however, that crowdout for the disabled was substantial. In a later robustness check, I derive a similarly large point estimate of crowd-out using an alternative sample from the March CPS. Since the estimates across the two samples are similar, this is suggestive that crowd-out in the disabled population was near $100 \%$.

The crowd-out measure and take-up rates for the disabled population in the 2SLS analysis are much larger than what has been previously found for other populations such as children and their

\footnotetext{
${ }^{19}$ Some crowd-out literature defines an alternative measure of crowd-out to be the percent change in Medicaid that is not associated with a reduction in the uninsurance rate. Since the analysis always finds an increase in the uninsurance rate, the alternative measure always suggests a crowd-out rate of over $100 \%$.

${ }^{20}$ Following the methods of Gruber and Simon (2008) we construct confidence intervals for the crowd-out measures using a clustered bootstrap with 350 replications. For each of the 350 replications we construct crowd-out measures accounting for and not accounting for the overlap group. We then take the 5th and 95th percentile of the constructed crowd-out measures to create the confidence intervals.
}

Journal of Health Economics, Vol. 40 (March 2015): pg. 69-82. DOI. This article is @ Elsevier and permission has been granted for this version to appear in e-Publications@Marquette. Elsevier does not grant permission for this article to be further copied/distributed or hosted elsewhere without the express permission from Elsevier. 
parents. There are several reasons this might be the case. First, the disabled are more likely to experience larger total healthcare expenses than children due to their chronic medical conditions requiring continuing treatment. Given this, private insurance plans for the disabled may have larger premiums, coinsurance, or deductibles making Medicaid insurance plans (which are free) a more attractive option. ${ }^{21}$

Second, disabled individuals may use the Medicaid expansions as a method of pursuing Social Security Disability Insurance (SSDI). Since most private health insurance is provided through an employer, the two year waiting period for Medicare coverage might discourage disabled individuals from securing SSDI coverage due to the "job lock" phenomenon. With the possibility of Medicaid coverage now available to them during the waiting period, individuals may have more incentive to leave their jobs (which often provide income above SSDI qualification levels) and take-up SSDI. If the majority of Medicaid take-up originates from individuals pursuing SSDI, then after the two year waiting period, costs to the Medicaid program will decrease as these individuals qualify for coverage through Medicare. Costs to SSDI will increase, however, as they have to provide Medicare for more participants. We leave detailed analysis of any increases in SSDI participation to future work.

\subsection{Robustness}

The basic results in Table 7 are robust to several alternative samples. We find similar effects of Medicaid expansions on public and private insurance coverage using the 1997 through 2008 March CPS from the Integrated Public-Use Microdata Series (IPUMS). The CPS is an annual, nationally representative survey that contains information on income, family structure, and health insurance status for the year prior to the interview. Similar to the SIPP analysis, the CPS sample is

\footnotetext{
${ }^{21}$ It is puzzling that all disabled individuals in the sample would choose to remain uninsured rather than accept Medicaid coverage. About sixteen percent of the disabled sample is uninsured which is not incredibly different from the insurance rate of the overall population during this time period. One possible explanation is that individuals with disabilities are more strongly influenced by social stigma than other types of individuals. Another explanation could be that disabled individuals lack the knowledge or ability to pursue the Medicaid application which is often a lengthy and complicated process.
}

Journal of Health Economics, Vol. 40 (March 2015): pg. 69-82. DOI. This article is (C) Elsevier and permission has been granted for this version to appear in e-Publications@Marquette. Elsevier does not grant permission for this article to be further copied/distributed or hosted elsewhere without the express permission from Elsevier. 
restricted to contain individuals between the ages of 20 and 64 who report having a work disability. We also drop all observations from the five states which are not uniquely identified within the SIPP. Thus, the SIPP and March CPS samples should represent similar populations. We impute Medicaid eligibility as we did in the SIPP analysis but adjust for annual Medicaid income limits and disregards to account for the yearly observations of the CPS. Simulated eligibility is constructed similarly except it is now at a state and year level.

Panel A of Table 9 reports two-stage-least-squares health insurance coverage estimates using the sample from the March CPS. The models in Table 9, Panel A have the same controls on the right side of the equation as in the SIPP analysis except they do not control for panel-wave fixed effects, which are specific to the survey structure of the SIPP. The health coverage variables (Medicaid only, Private only, Overlap, and Uninsurance) are defined the same as in the SIPP analysis. ${ }^{22}$ All estimates in Table 9, Panel $A$ are weighted using the State Health Access Data Assistance Center's (SHADAC) summary health insurance weight in the March CPS.

Results in Table 9, Panel A for the CPS analysis suggest a Medicaid take-up rate of $25 \%$ accompanied by a private reduction rate of $22 \%$. These rates are lower in magnitude than what was found in the SIPP analysis but may be partially explained by the longer recall period of the CPS. The Medicaid take-up rate and private reduction rates reported in columns (2) and (3) of Table 9, Panel A only account for changes in individuals reporting a single form of coverage for an entire year. The yearly observations in the CPS do not identify transitions in coverage as well as the monthly level data of the SIPP. As a result, individuals who experience transitions from one type of insurance to another are much more likely to appear in the overlap group in the CPS than in the SIPP. The increased likelihood of overlapping coverage potentially results in lower take-up rates for those reporting a single

\footnotetext{
${ }^{22}$ Health coverage variables for the CPS analysis are constructed using the health insurance summary variables produced by the State Health Access Data Assistance Center (SHADAC) contained within the IPUMS version of the CPS. The CPS updated their survey questionnaire in 1999 with a verification question to address the underreporting of health insurance. The verification question asked those who had not reported health coverage earlier in the survey about their health coverage again and allowed respondents a second chance to report forms of health coverage. SHADAC then imputed health insurance variables in the CPS prior to 1999 to account for the verification question.
}

Journal of Health Economics, Vol. 40 (March 2015): pg. 69-82. DOI. This article is (C) Elsevier and permission has been granted for this version to appear in e-Publications@Marquette. Elsevier does not grant permission for this article to be further copied/distributed or hosted elsewhere without the express permission from Elsevier. 
form of coverage, but larger take-up rates for those reporting two forms of coverage (i.e. private and Medicaid) in the CPS data. Indeed, the CPS estimate of the effect of Medicaid eligibility on overlap coverage is larger than the SIPP. If we account for this effect by interpreting it as a transition from private coverage to Medicaid, then the CPS estimates are closer to the level of the SIPP estimates but are still slightly lower in magnitude. This is consistent with Ham and Shore-Sheppard (2005) which found that take-up rates were more similar across the CPS and SIPP when SIPP responses were annualized to be more like CPS data. When we account for the overlap group, the CPS estimates suggest a crowd- out rate of $90 \%$ which is reasonably close to the SIPP estimates of crowd-out. A 95\% bootstrapped confidence interval, however, does not allow us to reject the null hypothesis for CPS estimates. The effect on uninsurance in column (5) of Table 9 Panel A is larger and statistically significant in the CPS suggesting a 1.31 percentage point increase for a 10 percentage point increase in Medicaid eligibility. There is no clear explanation as to why the uninsurance rate appears to be worsening in both samples. This is a focus of future work.

In order to qualify for Medicaid under the OBRA86 expansion, an individual must not only have a low level of income they must also be disabled. Though the definition of a self- reported work-limiting disability in the SIPP is probably less stringent than what is used by the government to determine disability status, it does identify a group of people likely to qualify for disability services. Since work disabilities in the SIPP are self-reported, we may be concerned that the Medicaid expansions increased the incentive to report a disability and resulted in a compositional shift of the sample across the time period. I find no evidence of an effect of eligibility on the likelihood of being workdisabled (results not shown) suggesting that becoming eligible for Medicaid did not induce a person to report a work disability. ${ }^{23}$

As a robustness test, we perform the same analysis as in Table 7 using non-work disabled individuals in the 1996, 2001, and 2004

\footnotetext{
${ }^{23}$ To test this, I run a 2SLS regression of an indicator for a reported work-related disability on an indicator for whether a respondent would be financially eligible for Medicaid using the same controls in my main analysis. The estimated effect of Medicaid financial eligibility on the likelihood of reporting disability status is -0.022 with a standard error of 0.065 .
}

Journal of Health Economics, Vol. 40 (March 2015): pg. 69-82. DOI. This article is @ Elsevier and permission has been granted for this version to appear in e-Publications@Marquette. Elsevier does not grant permission for this article to be further copied/distributed or hosted elsewhere without the express permission from Elsevier. 
panels of the SIPP. The results for this analysis are presented in Table 9, Panel B. There is no significant Medicaid take-up by non-work disabled individuals who would qualify for Medicaid based on their income alone (see column (2), Table 9, Panel B). In fact, the sign on the coefficient suggests there was a slight reduction in Medicaid participation for working age non-work disabled individuals though this result is not statistically significant. Medicaid eligibility also has small statistically insignificant effects on the other forms of coverage (Private only, Overlap, and Uninsured) for the non-work disabled. This supports the specification being properly identified.

One concern with the panel nature of the SIPP is the possibility of attrition bias. The response rates at the initial interview of each SIPP panel are higher than later interviews. We may be concerned that a select group of people choose not to respond or enter the dataset in later interviews and this influences the overall results. To account for this problem, we construct a baseline sample by keeping only observations from the first three waves of each panel and respondents who were present for the original interview (i.e. all entrants after the first wave of the panel are excluded). Table 9, Panel C displays the results from this restricted sample. Overall, the point estimates for private only coverage and Medicaid remain virtually unaffected though the estimates are less precise given the decrease in sample size and the effect on private insurance coverage loses statistical significance. The attrition sample also only contains observations from 3 years of data from my 12 year study period which does not allow us to take full advantage of the Medicaid eligibility expansions that vary by year. Despite their lack of statistical significance and poor precision, the point estimates of the effects on insurance coverage in the attrition analysis remain considerably close to the estimates of my main specification. This demonstrates that the results of the study are not being driven by attriters or entrants in the SIPP panels.

Another potential concern with the disabled population is its increased likelihood of being covered through Medicare. In earlier crowd-out studies for children, Medicare coverage was ignored given children's low tendency to be covered through this program. Crowdout literature has focused on the treatment of the overlap population for private and Medicaid coverage. We might also be concerned with the overlap population considering Medicare coverage. That is, we 
might want to account for individuals who report Medicaid and Medicare coverage or private and Medicare coverage in addition to private and Medicaid coverage. ${ }^{24}$ The interpretation for Medicare overlap groups will be different from the Medicaid-private overlap group. Given that Medicaid is a fully comprehensive plan, there is no need for Medicaid recipients to possess private coverage while covered by Medicaid. This is the basis for the original overlap assumption of a transition from private to public coverage. Medicare, though generous, is not completely comprehensive, however, and individuals often hold either supplementary private or Medicaid coverage to fill the gaps. ${ }^{25}$

Table 10 presents the results accounting for these additional Medicare overlap groups. Columns (1) and (2) of Table 10 present the results for private only (now no Medicaid or Medicare) and Medicaid only (now no private or Medicare) coverage. The results in column (2) of Table 10 suggests the increase in Medicaid coverage with no private or Medicare coverage is 2.39 percentage points for every 10 percentage point increase in eligibility. This is roughly equivalent to the decrease in private coverage with no Medicaid or Medicare coverage. Considering only these two groups, crowd-out remains large and consistent with the earlier specification (115\%). Turning to the Medicare overlap groups, there is a 1.78 percentage point decrease in Private-Medicare coverage for every 10 percentage point increase in Medicaid eligibility. This is slightly larger in magnitude than the increase in Medicaid-Medicare coverage which increases by 1.67 percentage points for a 10 percentage point increase in Medicaid eligibility. If we consider only these two coverage forms, the estimates imply a crowd-out rate of $107 \%$. Bootstrapped confidence intervals for crowd-out rates with and without Medicare coverage are wide and do not allow us to rule out zero crowd-out. Given the similarity in the magnitudes of the opposite signed coefficients of Medicaid only and private only and likewise Medicaid-Medicare and private-Medicare, however, the results suggest that individuals are choosing to take-up

\footnotetext{
${ }^{24}$ Very few individuals report all three forms of coverage in the same month in the SIPP.

${ }^{25}$ For Medicare eligible individuals, Medicare will always cover first-order expenses and Medicaid will cover any remaining charges.
}

Journal of Health Economics, Vol. 40 (March 2015): pg. 69-82. DOI. This article is @ Elsevier and permission has been granted for this version to appear in e-Publications@Marquette. Elsevier does not grant permission for this article to be further copied/distributed or hosted elsewhere without the express permission from Elsevier. 
NOT THE PUBLISHED VERSION; this is the author's final, peer-reviewed manuscript. The published version may be accessed by following the link in the citation at the bottom of the page.

Medicaid coverage over private coverage either as an individual policy or as a supplementary plan for Medicare. ${ }^{26}$

\section{Conclusion}

Despite the large cost and important Medicaid eligibility changes affecting the working age disabled population, little literature has examined the effects of Medicaid eligibility on insurance coverage for this group. In this paper, I fill this void by investigating a Medicaid eligibility expansion which allowed states the option to enroll disabled individuals with incomes up to $100 \%$ of the federal poverty level in Medicaid. Estimates of crowd-out range from 50 to $100 \%$ (OLS and 2SLS specifications, respectively). The 2SLS estimates suggest that all new Medicaid enrollees through the expansions dropped a private plan in favor of public coverage. The confidence interval around the 2SLS point estimate is wide, however, and should be interpreted cautiously, I find a similarly large point estimate of crowd-out using an alternative sample derived from the March CPS further supporting that crowd-out among the disabled population was substantial. Using population and disability rate information from 2008 (the year after the end of my study period), I estimate that these expansions cost at most between 2.92 to 3.03 billion dollars. ${ }^{27}$ We rely on the average cost of a disabled Medicaid recipient to construct these estimates, but it is likely that the newly eligible are not as expensive at the margin as the average disabled Medicaid recipient. Thus, we should think of 3 billion dollars as an upper bound of the cost of the expansions.

The analysis of these expansions is especially relevant given the enactment of the Medicaid expansions under the Patient Protection and Affordable Care Act in 2014. For states who accept the current terms of the PPACA, Medicaid eligibility levels will increase to include individuals under the age of 65 who have incomes less than $138 \%$ of

\footnotetext{
${ }^{26}$ If we interpret the overlap group between all three types of coverage as a transition to Medicaid Medicare- supplementary plans from Private Medicare-Supplementary plans, then crowd-out measures remain similar (130\%).

27 In 2008, approximately 15,000,000 individuals between the ages of 20 and 64 reported having a working limiting disability. Eligibility increased by roughly 3 percentage points at the peak of the expansions implying that close to 450,000 disabled people became eligible for Medicaid coverage. Using the estimated take-up rates (between 41 and $42 \%$ ) and an average cost per disabled beneficiary of $\$ 15,840$ (in FY 2008) this suggests that the expansions cost $450,000 * 0.41 * 15,840=\$ 2.92$ billion.
}

Journal of Health Economics, Vol. 40 (March 2015): pg. 69-82. DOI. This article is (C) Elsevier and permission has been granted for this version to appear in e-Publications@Marquette. Elsevier does not grant permission for this article to be further copied/distributed or hosted elsewhere without the express permission from Elsevier. 
the Federal Poverty Level. In 2008, the average income eligibility level for the disabled was $87 \%$ of the Federal Poverty Level across all states. Given the expansions imposed by the PPACA, we can expect more disabled individuals to become eligible for Medicaid in 2014. Disabled individuals qualifying through the overall Medicaid expansions of the PPACA are likely healthier on the margin than individuals qualifying through SSI. Given this, my estimates of total costs represent an upper bound, but are still informative as to the potential costs of the Medicaid expansion.

It is important to note that though I find the potential for fiscal consequences from these expansions, the results say nothing about any potential health benefits gained through the increased Medicaid take-up. Even though individuals are less reliant on private health insurance, they may experience benefits to health from receiving public coverage. First, private health insurance plans may not cover all services while Medicaid coverage provides for most procedures suggesting that individuals could gain access to medical techniques previously unavailable to them and improve overall physical health. Second, since Medicaid is a low cost (if not free) policy with virtually no copays or deductibles, individuals may benefit from having additional resources available for consumption. For many of these individuals, coverage through the Medicaid program will greatly lessen financial strain and can have an effect on mental health or overall happiness (Finkelstein et. al., 2012). Another potential benefit of disabled Medicaid coverage is that sicker individuals will leave employer group plans and result in smaller or slower growing insurance premiums for the privately insured individuals who remain on the plan.

There are some potential health detriments to Medicaid coverage, however. Due to low reimbursement rates, not all physicians will accept Medicaid coverage and beneficiaries are restricted to a limited group of health providers and may experience access problems. For adults with public health insurance, healthcare access is slightly worse than patients with private insurance (Government Accounting Office, 2012). There is also some evidence that the quality of care is worse for patients with public insurance compared with private insurance, but this difference is small (Weissman et al., 2013). Given these potential health benefits and detriments it is important to examine health 
NOT THE PUBLISHED VERSION; this is the author's final, peer-reviewed manuscript. The published version may be accessed by following the link in the citation at the bottom of the page.

outcomes in conjunction with the fiscal consequences. We leave the analysis of health outcomes to future work.

\section{Acknowledgements}

I would like to thank William Evans, Daniel Hungerman, James Sullivan, Ethan Lieber, Thomas DeLeire, Mark Duggan, the co-editor, two anonymous referees, and seminar participants at the University of Notre Dame.

\section{References}

Aizer, A. \& Grogger, J. (2003). Parental Medicaid expansions and child Medicaid coverage. NBER Working Paper \# 9907.

Anderson, W.L, Armour, B.S., Finkelstein, E.A., \& Wiener, J.M. (2010). Estimates of state-level health-care expenditures associated with disability. Public Health Reports 125, 44-51.

Autor, D. H. \& Duggan, M. G. (2003). The rise in the disability roles and the decline in unemployment. The Quarterly Journal of Economics 118(1), 157-205.

. (2006). The growth in the social security disability rolls: a fiscal crisis unfolding. Journal of Economic Perspectives 20(3), 71-96.

. (2007). Distinguishing income from substitution effects in disability insurance. The American Economic Review 97(2), 119-124.

Baicker, K., Finkelstein, A., Song J., \& Taubman, S. (2013). The impact of Medicaid on labor force activity and program participation: Evidence from the Oregon Health Insurance Experiment. NBER Working Paper \#19547

Baumrucker, E. (2010). Medicaid: The Federal Medical Assistance Percetange (FMAP). Congressional Research Service.

Blumberg, L.J, Dubay, L. \& Norton, S.A. (2000). Did the Medicaid expansions for children displace private insurance? An analysis using the SIPP. Journal of Health Economics 19(1), 33-60.

Brown, J.R., Coe, N. \& Finkelstein, A. (2007). Medicaid crowd-out of private long-term care insurance demand: evidence from the Health and Retirement Survey. Tax Policy and the Economy 21, 1-34.

Bruen, B.K., Wiener, J.M., Kim, J. \& Miazad, O. (1999). State usage of Medicaid coverage options for aged blind, and disabled people. Assessing the New Federalism Discussion Papers.

Journal of Health Economics, Vol. 40 (March 2015): pg. 69-82. DOI. This article is @ Elsevier and permission has been granted for this version to appear in e-Publications@Marquette. Elsevier does not grant permission for this article to be further copied/distributed or hosted elsewhere without the express permission from Elsevier. 
NOT THE PUBLISHED VERSION; this is the author's final, peer-reviewed manuscript. The published version may be accessed by following the link in the citation at the bottom of the page.

Bruen, B.K., Wiener, J.M., \& Thomas, S. (2003). Medicaid eligibility policy for aged, blind, and disabled beneficiaries. The Urban Institute.

Buettgens, M. (2011). Health Insurance Policy Simulation Model (HIPSM) Methodology Documentation. The Urban Institute.

Burkhauser, R.V., Houtenville, A.J., \& Wittenburg, D.C. (2003). A user guide to current statistics on the employment of people with disabilities. Rehabilitation Research and Training Center for Economic Research on Employment Policy for Persons with Disabilities.

Card, D. \& Shore-Sheppard, L. (2004). Using discontinuous eligibility rules to identify the effects of the federal medicaid expansions on low income children. Review of Economics and Statistics 86(3), 752-766.

Centers for Disease Control and Prevention. Disability and Health Data System (DHDS). Updated March 2011; cited 2006. Available from: http://dhds.cdc.gov.

Centers for Medicare and Medicaid Services. (2010). 2010. 2010 Actuarial Report: On the financial outlook for Medicaid. United States Department of Health and Human Services.

. (2009). National health expenditure fact sheet. Retrieved July 28, 2012 from https://www.cms.gov/Research-Statistics-Data-andSystems/Statistics-Trends-andReports/NationalHealthExpendData/NHE-Fact-Sheet.html.

. (2012). Medicaid benefits. Retrieved from http://www.medicaid.gov/Medicaid-CHIP- Program-Information/ByTopics/Benefits/Medicaid-Benefits.html

Coburn, A.F., Long, S.H., \& Marquis, M.S. (1999). Effects of changing Medicaid fees on physician participation and enrollee access. Inquiry 36(3), 265-279.

Coe, N.B. (2005). Financing nursing home care: New evidence on spenddown behavior. MIT dissertation.

Congressional Research Service. (1993). Medicaid Source Book: Background data and analysis.

Currie, J., Decker, S. \& Wanchuan L. (2008). Has public health insurance for older children reduced disparities in access to care and health outcomes? Journal of Health Economics 27, 1567-1581.

Currie, J. \& Gruber, J. (1996a). Health insurance eligibility, utilization of medical care, and child health. Quarterly Journal of Economics 111, 431-466.

Journal of Health Economics, Vol. 40 (March 2015): pg. 69-82. DOI. This article is (C) Elsevier and permission has been granted for this version to appear in e-Publications@Marquette. Elsevier does not grant permission for this article to be further copied/distributed or hosted elsewhere without the express permission from Elsevier. 
NOT THE PUBLISHED VERSION; this is the author's final, peer-reviewed manuscript. The published version may be accessed by following the link in the citation at the bottom of the page.

. (1996b). Saving Babies: The efficacy and cost of recent changes in the Medicaid eligibility of pregnant women. Journal of Political Economy, 104(6), 1263-1296.

Currie, J., Gruber, J., \& Fischer, M. (1995). Physician payments and infant health: Effect of increases in Medicaid reimbursement. American Economic Review 85, 106-111.

Cutler, D. \& Gruber, J. (1996). Does public health insurance crowd-out private insurance? Quarterly Journal of Economics 111, 391-430.

Dafny, L. \& Gruber, J. (2005). Public insurance and child hospitalizations: Access and efficiency effects. Journal of Public Economics, 89(1), 109129.

Davern, M., Klerman, J.A., Baugh, D.K., Call, K.T., \& Greenberg, G.D. (2009). An examination of the Medicaid undercount in the current population survey: preliminary results from record linking. Health Services Research 44(3), 965-987.

De Nardi, M., French, E., Jones, J.B., \& Gooptu, A. (2011). Medicaid and the elderly. NBER Working Paper \# 17689.

Dubay, L.C. \& Kenney, G. (1996). Revisiting the issues: the effects of Medicaid expansions on insurance coverage of children. The Future of Children 6(1), 152-161.

Dubay, L.C. \& Kenney, G. (1997). Did Medicaid expansions for pregnant women crowd-out private insurance? Health Affairs 16(1), 185-193.

Duggan, M., Singleton, P., \& Song, J. (2007). Aching to retire? The rise in the full retirement age and its impact on the social security disability rolls. Journal of Public Economics 91, 1327-1350.

Duggan, M., \& Imberman, S.A. (2009). Why are the disability rolls skyrocketing? The contribution of population characteristics, economic conditions, and program generosity. In (D.M. Cutler \& D.A. Wise, Eds.). Health at Older Ages: The Causes and Consequences of Declining Disability among the Elderly. (pp. 337-379). University of Chicago Press.

Families USA. (2001). Could your state do more to expand Medicaid for seniors and adults with disabilities? Expanding Medicaid: State options. Washington D.C.

Finkelstein, A., Taubman, S., Wright, B. Bernstein, M., Gruber, J., Newhouse, J.P., Allen, H., Baicker, K. \& Oregon Health Study Group. (2012). The

Journal of Health Economics, Vol. 40 (March 2015): pg. 69-82. DOI. This article is @ Elsevier and permission has been granted for this version to appear in e-Publications@Marquette. Elsevier does not grant permission for this article to be further copied/distributed or hosted elsewhere without the express permission from Elsevier 
NOT THE PUBLISHED VERSION; this is the author's final, peer-reviewed manuscript. The published version may be accessed by following the link in the citation at the bottom of the page.

Oregon Health Insurance Experiment: Evidence from the first year. The Quarterly Journal of Economics 127(3), 1057-1106.

Fleming, C. (2010). Medicaid spending growth exceeds expectations. Health Affairs Blog. Retrieved July 27, 2012 from http://healthaffairs.org/blog/2010/09/30/medicaid- spending-growthexceeds-expectations/.

Garthwaite, C. (2012). The doctor might see you now: the supply side effects of public health insurance expansions. American Economic Journal: Economic Policy 4(3), 190-215.

Garthwaite, C., Gross, T. \& Notowidigdo, M.J. (2013). Public health insurance, labor supply, and employment lock. NBER Working Paper No. 1922.

Grabowski, D.C., Ohsfeldt, R.L., \& Morrisey, M.A. (2003). Inquiry - Excellus Health Plan 40(2), 146-157.

Gruber, J. \& Simon, K. (2008). Crowd-out 10 years later: Have recent public insurance expansions crowded out private health insurance? Journal of Health Economics, 27, 201- 217.

Gruber, J. \& Kubik, J. (2002). Health insurance coverage and the disability insurance Application Decision. NBER Working Paper No. 9148.

Ham, J. \& Shore-Sheppard, L. (2005). The effect of Medicaid expansions for low-income children on Medicaid participation and private insurance coverage: evidence from the SIPP. Journal of Public Economics 89, 5783.

Hamersma, S. (2010). The effects of Medicaid earnings limits on earnings growth among poor workers. Working Paper.

Hamersma, S. \& Kim, M. (2013). Participation and crowd out: Assessing the effects of parental Medicaid expansions. Journal of Health Economics $32,160-171$.

Herz, E.J., Hearne, J., Stone, J., Tritz, K., Baumrucker, E.P., Scott, C., Peterson, C.L., Grady, A., and Rimkunas, R. (2006). How Medicaid Works - Program Basics. January 4, 2006 Update. Congressional Research Service.

Holahan, J., Buettgens, M, Carroll, C. \& Dorn, S. (2012). The cost and coverage implications of the ACA Medicaid expansion: National and state-by-state analysis - Executive Summary. Kaiser Commission on Medicaid and the Uninsured. Retrieved August 29, 2013 from http://kaiserfamilyfoundation.files.wordpress.com/2013/01/8384_es.p df

Journal of Health Economics, Vol. 40 (March 2015): pg. 69-82. DOI. This article is @ Elsevier and permission has been granted for this version to appear in e-Publications@Marquette. Elsevier does not grant permission for this article to be further copied/distributed or hosted elsewhere without the express permission from Elsevier 
NOT THE PUBLISHED VERSION; this is the author's final, peer-reviewed manuscript. The published version may be accessed by following the link in the citation at the bottom of the page.

Horvath, J. (1997). Medicaid financial eligibility for aged, blind, and disabled: Survey of state use of selected options. National Academy for State Health Policy

Hudson, J., Selden, T. \& Banthin, J. (2005). Impact of SCHIP on insurance coverage of children. Inquiry 42(3), 232-254.

Kaiser Family Foundation. (2008). Medicaid: A timeline of key developments. Retrieved July 27, 2012 from http://kaiserfamilyfoundation.files.wordpress.com/2008/04/5-02-13medicaid-timeline.pdf.

. (2012). Quick take: Who benefits from the ACA Medicaid expansion? Retrieved August 22, 2013 from http://kff.org/health-reform/factsheet/who-benefits-from-the-aca- medicaid-expansion/

. (2014). Status of state action on the Medicaid expansion decision, 2014. Retrieved June 5, 2014 from http://kff.org/health-reform/stateindicator/state-activity-around-expanding- medicaid-under-theaffordable-care-act/\#

Kaiser Family Foundation: statehealthfacts.org. Medicaid \& CHIP data.

Kaiser Commission on Medicaid and the Uninsured. (2010). Medicaid financial eligibility: primary pathways for the elderly and people with disabilities. Kaiser Family Foundation.

Kassner, E. \& Shirley, L. (2000). Medicaid financial eligibility for older people: State variations in access to home and community-based waiver and nursing home services." The Public Policy Institute, AARP.

King, M., Ruggles, S., Alexander, J.T., Flood, S., Genadek, K., Schroeder, M.B., Rampe, B., \& Vick, R. (2010). Integrated Public Use Microdata Series, Current Population Survey: Version 3.0. [Machine-readable database]. Minneapolis, MN: Minnesota Population Center [producer and distributor].

Lakdawalla, D.N., Bhattacharya, J. \& Goldman, D.P. (2004). Are the young becoming more disabled? Health Affairs 23(1), 168-176.

Livermore, G., Stapleton, D. \& Claypool, H. (2009). Health insurance and health care access before and after SSDI entry. Mathematica Policy Research, Inc.

LoSasso, A. \& Buchmueller, T. (2004). The effect of the state children's health insurance program on health insurance coverage. Journal of Health Economics 23, 1059-1082.

Journal of Health Economics, Vol. 40 (March 2015): pg. 69-82. DOI. This article is @ Elsevier and permission has been granted for this version to appear in e-Publications@Marquette. Elsevier does not grant permission for this article to be further copied/distributed or hosted elsewhere without the express permission from Elsevier 
NOT THE PUBLISHED VERSION; this is the author's final, peer-reviewed manuscript. The published version may be accessed by following the link in the citation at the bottom of the page.

McIsaac, C. (2011). Insuring Arizona: Preserving AHCCCS coverage in a challenging economy. Arizona Chamber Foundation Policy Brief.

Meyer, B.D. \& Wherry, L. R. (2012). Saving teens: using a policy discontinuity to estimate the effects of Medicaid eligibility. NBER Working Paper 18309.

Mississippi Division of Medicaid. (1991-2008). Annual Report.

Mitchell, J.B. (1991). Physician participation in Medicaid revisited. Medical Care 29(7), 645- 653.

Smith, V. K., Gifford, K., Ellis, E., Rudowitz, R., and Snyder, L. (2011). Moving ahead amid fiscal challenges: A look at Medicaid spending, coverage and policy trends. Results from a 50-state Medicaid budget survey for state fiscal years 2011 and 2012. Kaiser Commission on Medicaid and the Uninsured.

Shore-Sheppard, L. D. "Stemming the tide? The effect of expanding Medicaid eligibility on health insurance." The B.E. Journal of Economic Analysis \& Policy 8, 2 (2008): Article 6.

Social Security Administration. (2012). Understanding Supplemental Security Income. Retrieved July 27, 2012 from http://www.ssa.gov/ssi/textunderstanding-ssi.htm.

. (1991-2008). State assistance programs for SSI recipients. SSA Publication No. 13- 11975.

Stone, J.L. (2002). Medicaid: Eligibility for the aged and disabled. Report for Congress. Congressional Research Service.

. (2011). Medicaid eligibility for persons age 65+ and individuals with disabilities: 2009 state profiles. Congressional Research Service.

Thorpe, K. \& Florence, C. (1998). Health insurance coverage among children: the role of expanded Medicaid coverage. Inquiry 35(4), 369-379.

United States Census Bureau. (2012). Disability: CPS Annual Social and Economics Supplement (CPS ASEC). Retrieved January 21, 2014 from http://www.census.gov/people/disability/methodology/cps.html. . (1996). Survey of Income and Program Participation 1996 Panel Wave 1 Core Microdata File.

United States Department of Health and Human Services. (2009). The 2009 HHS Federal Poverty Guidelines. Retrieved July 28, 2012 from http://aspe.hhs.gov/poverty/09poverty.shtml/09fedreg.shtml.

Journal of Health Economics, Vol. 40 (March 2015): pg. 69-82. DOI. This article is @ Elsevier and permission has been granted for this version to appear in e-Publications@Marquette. Elsevier does not grant permission for this article to be further copied/distributed or hosted elsewhere without the express permission from Elsevier 
NOT THE PUBLISHED VERSION; this is the author's final, peer-reviewed manuscript. The published version may be accessed by following the link in the citation at the bottom of the page.

United States Department of Labor. (2012). FAQs for employees about COBRA continuation health coverage. Retrieved September 18, 2012 from http://www.dol.gov/ebsa/faqs/faq- consumer-cobra.html

United States Government Accountability Office. (2012). States made multiple program changes, and beneficiaries generally reported access comparable to private insurance. Report to the Secretary of Health and Human Services.

Urban Institute. Transfer Income Model 3 Documentation - Medicaid version 65.1. Retrieved July 28, 2012 from http://trim3.urban.org/documentation/Medicaid/Main.php.

Weissman, J.S., Vogeli, C., \& Levy, D.E. (2013). The quality of hospital care for Medicaid and private pay patients. Medical Care, 51(5), 389-395.

Yazici, E. \& Kaestner, R. (2000). Medicaid expansions and the crowding out of private health insurance among children. Inquiry 37(Spring 1), 23-32.

Yelowitz, A.S. (1995). The Medicaid notch, labor supply, and welfare participation: Evidence from eligibility expansions. The Quarterly Journal of Economics 110(4), 909-939.

Zuckerman, S., McFeeters, J., Cunningham, P., \& Nichols, L. (2004). Changes in Medicaid physician fees, 1998-2003: implications for physician participation. Health Affairs, 23(4), 374-384.

Journal of Health Economics, Vol. 40 (March 2015): pg. 69-82. DOI. This article is (C) Elsevier and permission has been granted for this version to appear in e-Publications@Marquette. Elsevier does not grant permission for this article to be further copied/distributed or hosted elsewhere without the express permission from Elsevier. 
NOT THE PUBLISHED VERSION; this is the author's final, peer-reviewed manuscript. The published version may be accessed by following the link in the citation at the bottom of the page.

Table 1. Medicaid upper income thresholds for the disabled population: 1996 and 2007.

\begin{tabular}{|c|c|c|c|c|c|}
\hline \multirow[t]{2}{*}{ State } & \multicolumn{2}{|c|}{$\begin{array}{c}\text { Income Eligibility Limit } \\
(\% \mathrm{FPL})\end{array}$} & \multirow[t]{2}{*}{ State } & \multicolumn{2}{|c|}{$\begin{array}{c}\text { Income Eligibility Limit } \\
(\% \mathrm{FPL})\end{array}$} \\
\hline & 1996 & 2007 & & 1996 & 2007 \\
\hline $\mathrm{AK}$ & 131 & $117 * *$ & MT & 74 & 74 \\
\hline AL & 82 & 80 & $\mathrm{NC}$ & 74 & 100 \\
\hline $\mathrm{AR}$ & 74 & 80 & $N D$ & 74 & 74 \\
\hline $\mathrm{AZ}$ & 74 & $100^{*}$ & $\mathrm{NE}$ & 100 & 100 \\
\hline CA & 99 & 100 & $\mathrm{NH}$ & 79 & 77 \\
\hline $\mathrm{CO}$ & 83 & 77 & NJ & 100 & 100 \\
\hline$C T$ & 118 & 94 & $\mathrm{NM}$ & 74 & 74 \\
\hline DC & 100 & 100 & NV & 80 & 78 \\
\hline $\mathrm{DE}$ & 74 & 74 & NY & 88 & 84 \\
\hline FL & 90 & 88 & $\mathrm{OH}$ & 63 & 64 \\
\hline GA & 74 & 100 & $O K$ & 83 & 100 \\
\hline$H I$ & 115 & $115^{*}$ * & OR & 74 & 74 \\
\hline IA & 74 & 74 & $\mathrm{PA}$ & 100 & 100 \\
\hline ID & 80 & 78 & RI & 84 & 100 \\
\hline$I L$ & 48 & 100 & $\mathrm{SC}$ & 100 & 100 \\
\hline$I N$ & 74 & 74 & $\mathrm{SD}$ & 76 & 76 \\
\hline $\mathrm{KS}$ & 74 & 74 & $\mathrm{TN}$ & 74 & 74 \\
\hline $\mathrm{KY}$ & 74 & 74 & $\mathrm{TX}$ & 74 & 74 \\
\hline LA & 74 & 74 & UT & 74 & 100 \\
\hline MA & 133 & $133^{*}$ & $V A$ & 74 & 80 \\
\hline $\mathrm{MD}$ & 74 & 74 & VT & 80 & 80 \\
\hline ME & 100 & 100 & WA & 78 & 78 \\
\hline MI & 76 & 100 & WI & 87 & 84 \\
\hline$M N$ & 85 & 95 & WV & 74 & 74 \\
\hline MO & 74 & 85 & WY & 74 & 74 \\
\hline MS & 100 & 100 & & & \\
\hline
\end{tabular}

Bold and italicized states are those using the 209(b) option.

* Arizona offers Medicaid eligibility for those at or below 100\% FPL through the Arizona Health Care Cost Containment System. This system was formed through a special demonstration waiver (Section 1115). Massachusetts extends Medicaid eligibility even further to $133 \%$ FPL using a Section 1115 demonstration as well.

** Hawaii and Alaska have higher federal poverty levels than the continental United States. The upper income limits for these two states are constructed relative to the poverty level of the 48 remaining states.

Journal of Health Economics, Vol. 40 (March 2015): pg. 69-82. DOI. This article is (C) Elsevier and permission has been granted for this version to appear in e-Publications@Marquette. Elsevier does not grant permission for this article to be further copied/distributed or hosted elsewhere without the express permission from Elsevier. 
NOT THE PUBLISHED VERSION; this is the author's final, peer-reviewed manuscript. The published version may be accessed by following the link in the citation at the bottom of the page.

Table 2: Summary Statistics for SIPP Individuals Reporting a Work Disability by Eligibility Status.

\begin{tabular}{lcc}
\hline \hline Variable & Ineligible Sample & Eligible Sample \\
\hline & & \\
Average Age & 50 & 45 \\
\% Female & 0.42 & 0.59 \\
\% Black & 0.14 & 0.21 \\
\% Married & 0.53 & 0.41 \\
\% No High School & 0.17 & 0.33 \\
\% High School & 0.31 & 0.35 \\
\% College & 0.51 & 0.33 \\
Average Real Monthly Personal Income & $\$ 2,816.18$ & $\$ 503.70$ \\
\% Medicaid & 0.13 & 0.47 \\
\% Medicare & 0.32 & 0.16 \\
\% Private & 0.67 & 0.34 \\
\% Uninsured & 0.12 & 0.25 \\
Average Number of Children & 0.52 & 0.57 \\
Average Family Size & 2.47 & 2.68 \\
\% Employed & 0.46 & 0.22 \\
\% Receiving SSI & 0.06 & 0.31 \\
Observations & 72,678 & 98,231 \\
Number of Individuals & 23,399 & 27,448 \\
\hline \hline
\end{tabular}

Summary statistics are weighted using the individual weight in the 1996,2001 , and 2004 SIPP panels. I can reject the null at a $P$-value of 0.01 that the sample means are the same across samples for all variables. 9293 individuals were in both the ineligible and eligible samples over the time period resulting in a total of 41,554 individuals included throughout the entire analysis.

Table 3: Pre and Post Trends in State Insurance Coverage Rates Work Disabled Sample 1992-2008 March CPS

\begin{tabular}{lcccc}
\hline \hline & $\begin{array}{c}\text { Medicaid Only } \\
(1)\end{array}$ & $\begin{array}{c}\text { Private Only } \\
(2)\end{array}$ & $\begin{array}{c}\text { Overlap } \\
(3)\end{array}$ & $\begin{array}{c}\text { Uninsurance } \\
(4)\end{array}$ \\
\cline { 2 - 5 } & & & & \\
& 0.0010 & 0.0008 & -0.0005 & 0.0008 \\
Pre-Adoption Trend & $(0.0018)$ & $(0.0016)$ & $(0.0006)$ & $(0.0013)$ \\
& & & & -0.0001 \\
Post-Adoption Trend & $0.0049^{* * *}$ & $-0.0034^{*}$ & -0.0001 & $(0.0012)$ \\
& $(0.0016)$ & $(0.0020)$ & $(0.0005)$ & 0.14 \\
Mean(Ins. Rate) & 0.27 & & & 867 \\
Observations & 867 & 0.40 & 0.04 & 867 \\
R-squared & 0.6913 & 0.6806 & 0.3498 & 0.5885 \\
\hline \hline
\end{tabular}

Notes: Results are from the 1992-2008 March CPS. Regressions are OLS regressions of four types of state insurance coverage rates (Medicaid only, Private Only, Both Medicaid and Private, and Uninsured) on a pre-adoption trend and a post-adoption

Journal of Health Economics, Vol. 40 (March 2015): pg. 69-82. DOI. This article is @ Elsevier and permission has been granted for this version to appear in e-Publications@Marquette. Elsevier does not grant permission for this article to be further copied/distributed or hosted elsewhere without the express permission from Elsevier. 
NOT THE PUBLISHED VERSION; this is the author's final, peer-reviewed manuscript. The published version may be accessed by following the link in the citation at the bottom of the page.

trend. All regressions control for state and year fixed effects. Standard errors are clustered at the state level. * Represents a $10 \%$ significance level. ${ }^{* *}$ Represents a $5 \%$ significance level. $* * *$ Represents a $1 \%$ significance level. All regressions are weighted using the SHADAC constructed weight for CPS health insurance coverage.

Table 4: Changes in Health Insurance Coverage, 1996 to 2007, by Income Group Work Disability Sample from 1996, 2001, and 2004 SIPP Panels

\begin{tabular}{|c|c|c|c|c|}
\hline Income Group & Eligibility & $\begin{array}{l}\text { Medicaid } \\
\text { only }\end{array}$ & $\begin{array}{l}\text { Private } \\
\text { only }\end{array}$ & Overlap \\
\hline & (1) & $(2)$ & (3) & (4) \\
\hline \multirow[t]{2}{*}{$<=74 \% \mathrm{FPL}$} & 0.010 & 0.035 & -0.025 & $0.024 * * *$ \\
\hline & $(0.008)$ & $(0.024)$ & $(0.017)$ & $(0.007)$ \\
\hline \multirow[t]{2}{*}{$74-100 \% \mathrm{FPL}$} & $0.207 * *$ & $0.124 * * *$ & $-0.095 * * *$ & $0.043 * *$ \\
\hline & $(0.078)$ & $(0.044)$ & $(0.029)$ & $(0.016)$ \\
\hline \multirow[t]{2}{*}{$100-150 \% \mathrm{FPL}$} & 0.002 & 0.000 & $-0.075 * * *$ & $0.043 * * *$ \\
\hline & $(0.011)$ & $(0.020)$ & $(0.026)$ & $(0.012)$ \\
\hline \multirow[t]{2}{*}{$150 \%+\mathrm{FPL}$} & 0.000 & $0.021 *$ & $-0.049 * *$ & $0.042 * * *$ \\
\hline & $(0.000)$ & $(0.011)$ & $(0.021)$ & $(0.009)$ \\
\hline \multirow{3}{*}{$\begin{array}{l}\text { All groups (except } 74- \\
100 \% \text { FPL) }\end{array}$} & -0.013 & 0.021 & $-0.037 * * *$ & $0.032 * * *$ \\
\hline & $(0.010)$ & $(0.016)$ & $(0.010)$ & $(0.004)$ \\
\hline & \multicolumn{4}{|c|}{ Difference-in-Difference Estimates } \\
\hline $74-100 \%$ relative to $<=74 \%$ & $0.198 * *$ & $0.090 *$ & $-0.070 * *$ & 0.019 \\
\hline FPL & $(0.075)$ & $(0.045)$ & $(0.027)$ & $(0.015)$ \\
\hline $74-100 \%$ relative to $100-$ & $0.206^{* *}$ & $0.124 * *$ & -0.020 & 0.000 \\
\hline $150 \% \mathrm{FPL}$ & $(0.080)$ & $(0.047)$ & $(0.038)$ & $(0.019)$ \\
\hline $74-100 \%$ relative to $150 \%+$ & $0.207 * *$ & $0.104 * *$ & -0.045 & 0.001 \\
\hline FPL & $(0.078)$ & $(0.048)$ & $(0.037)$ & $(0.020)$ \\
\hline $74-100 \%$ relative to All & $0.220 * * *$ & $0.104 * *$ & $-0.056 * *$ & 0.011 \\
\hline Others & $(0.073)$ & $(0.045)$ & $(0.028)$ & $(0.016)$ \\
\hline
\end{tabular}

Notes: Standard errors are in parentheses and are clustered at the state level. Income groups are based on countable income as a percent of the federal poverty level. Sample sizes are 12,888 in $<=74 \%$ FPL group, 2467 in $74-100 \%$ FPL group, 3400 in $100-150 \%$ FPL group, 5533 in 150\% + FPL group. Overlap represents respondents who report having both private and Medicaid coverage. Medicaid represents respondents reporting Medicaid and no private coverage. Private represents respondents reporting private and no Medicaid coverage. Results are weighted using the individual weight from the SIPP. * Represents a $10 \%$ significance level. ** Represents a $5 \%$ significance level. *** Represents a $1 \%$ significance level. Source: Author's calculation

Journal of Health Economics, Vol. 40 (March 2015): pg. 69-82. DOI. This article is (C) Elsevier and permission has been granted for this version to appear in e-Publications@Marquette. Elsevier does not grant permission for this article to be further copied/distributed or hosted elsewhere without the express permission from Elsevier. 
NOT THE PUBLISHED VERSION; this is the author's final, peer-reviewed manuscript. The published version may be accessed by following the link in the citation at the bottom of the page.

Table 5: Crowd-out from Difference-in-Difference Analysis Work Disability Sample from 1996, 2001, and 2004 SIPP Panels

\begin{tabular}{ccc}
\hline \hline Income Group & No Overlap & Overlap \\
\hline & $(1)$ & $(2)$ \\
$74-100 \%$ relative to $<=74 \%$ FPL & $0.778 * * *$ & $0.819^{* * *}$ \\
& $(0.273)$ & $(0.256)$ \\
$74-100 \%$ relative to $100-150 \%$ FPL & 0.161 & 0.163 \\
& $(0.305)$ & $(0.341)$ \\
$74-100 \%$ relative to $150 \%+$ FPL & 0.433 & 0.446 \\
& $(0.340)$ & $(0.383)$ \\
$74-100 \%$ relative to All Others & $0.538^{* *}$ & $0.603 * *$ \\
& $(0.245)$ & $(0.254)$ \\
\hline \hline
\end{tabular}

Notes: Standard errors are in parentheses and are constructed from Table 4 estimates using the delta method. The table contains crowd-out measures using difference-indifference estimates in Table 4. The "No Overlap" column does not account for the population reporting both private and Medicaid insurance coverage. The "Overlap" column accounts for this population assuming that the change in overlap coverage represents a transition from private to public coverage. Income groups represent monthly income of the individual minus Medicaid disregards as a percent of the federal poverty level. ${ }^{*}$ Represents a $10 \%$ significance level. ** Represents a $5 \%$ significance level. *** Represents a $1 \%$ significance level.

Source: Author's calculation.

Journal of Health Economics, Vol. 40 (March 2015): pg. 69-82. DOI. This article is @ Elsevier and permission has been granted for this version to appear in e-Publications@Marquette. Elsevier does not grant permission for this article to be further copied/distributed or hosted elsewhere without the express permission from Elsevier. 
NOT THE PUBLISHED VERSION; this is the author's final, peer-reviewed manuscript. The published version may be accessed by following the link in the citation at the bottom of the page.

Table 6: OLS Estimates of Insurance Coverage Regressions, Work Disability Sample from 1996, 2001, and 2004 SIPP Panels

\begin{tabular}{|c|c|c|c|c|}
\hline \multirow[t]{2}{*}{ Dep. Var. } & $\begin{array}{c}\text { Medicaid } \\
\text { Only }\end{array}$ & Private Only & Overlap & Uninsurance \\
\hline & (1) & (2) & (3) & (4) \\
\hline Eligible & $\begin{array}{c}0.290^{* * * *} \\
(0.011)\end{array}$ & $\begin{array}{c}-0.142 * * * \\
(0.010)\end{array}$ & $\begin{array}{c}0.025^{* * * *} \\
(0.003)\end{array}$ & $\begin{array}{c}0.075^{* * *} * \\
(0.006)\end{array}$ \\
\hline Female & $\begin{array}{c}0.017 * * * \\
(0.005)\end{array}$ & $\begin{array}{c}0.078^{* * *} * \\
(0.006)\end{array}$ & $\begin{array}{l}-0.002 \\
(0.002)\end{array}$ & $\begin{array}{c}-0.068 * * * \\
(0.003)\end{array}$ \\
\hline Black & $\begin{array}{c}0.096^{* * *} * \\
(0.008)\end{array}$ & $\begin{array}{c}-0.091 * * * \\
(0.009)\end{array}$ & $\begin{array}{c}0.003 \\
(0.003)\end{array}$ & $\begin{array}{c}-0.022 * * * \\
(0.007)\end{array}$ \\
\hline Hispanic & $\begin{array}{c}0.036 \\
(0.028)\end{array}$ & $\begin{array}{c}-0.062 * * * \\
(0.015)\end{array}$ & $\begin{array}{c}-0.013 * * * \\
(0.004)\end{array}$ & $\begin{array}{c}0.043^{* * *} * \\
(0.015)\end{array}$ \\
\hline No High School & $\begin{array}{c}0.194 * * * \\
(0.009)\end{array}$ & $\begin{array}{c}-0.243 * * * \\
(0.007)\end{array}$ & $\begin{array}{c}0.003 \\
(0.004)\end{array}$ & $\begin{array}{c}0.006 \\
(0.008)\end{array}$ \\
\hline High School & $\begin{array}{c}0.080^{* * * *} \\
(0.005)\end{array}$ & $\begin{array}{c}-0.110 * * * \\
(0.005)\end{array}$ & $\begin{array}{c}0.007^{* * *} * \\
(0.002)\end{array}$ & $\begin{array}{c}0.020 * * * \\
(0.004)\end{array}$ \\
\hline Married & $\begin{array}{c}-0.197 * * * \\
(0.006)\end{array}$ & $\begin{array}{c}0.310 * * * \\
(0.009)\end{array}$ & $\begin{array}{c}-0.014 * * * \\
(0.003)\end{array}$ & $\begin{array}{c}-0.061 * * * \\
(0.004)\end{array}$ \\
\hline Mean of Dep. Variable & 0.29 & 0.42 & 0.04 & 0.19 \\
\hline R-squared & 0.2558 & 0.3258 & 0.0196 & 0.0698 \\
\hline
\end{tabular}

Notes: Results are from the 1996, 2001, and 2004 panels of the SIPP. Regressions are OLS regressions of four forms of health coverage (Medicaid only, Private Only, Both Medicaid and Private, and Uninsured) on imputed Medicaid eligibility. All models included 170,909 observations and control for panel-wave, state and year fixed effects, a state-linear trend, age, age squared, a cubic in income, number of children in household, and family size. Standard errors are clustered at the state level. * Represents a $10 \%$ significance level. ${ }^{* *}$ Represents a $5 \%$ significance level. $* * *$ Represents a $1 \%$ significance level. All regressions are weighted using the SIPP provided person-level weight. Source: Author's calculation.

Journal of Health Economics, Vol. 40 (March 2015): pg. 69-82. DOI. This article is @ Elsevier and permission has been granted for this version to appear in e-Publications@Marquette. Elsevier does not grant permission for this article to be further copied/distributed or hosted elsewhere without the express permission from Elsevier. 
NOT THE PUBLISHED VERSION; this is the author's final, peer-reviewed manuscript. The published version may be accessed by following the link in the citation at the bottom of the page.

Table 7: First-Stage Estimates for and 2SLS Estimates of Insurance Coverage Regressions, Work Disability Sample from 1996, 2001, and 2004 SIPP Panels

\begin{tabular}{|c|c|c|c|c|c|}
\hline \multirow[b]{2}{*}{$\begin{array}{l}\text { Dependent } \\
\text { Variable }\end{array}$} & \multirow{2}{*}{$\begin{array}{l}\text { First-Stage } \\
\text { Eligible } \\
(1)\end{array}$} & \multicolumn{4}{|c|}{ 2SLS Estimates } \\
\hline & & $\begin{array}{l}\text { Medicaid } \\
\text { Only } \\
(2) \\
\end{array}$ & $\begin{array}{l}\text { Private } \\
\text { Only } \\
(3)\end{array}$ & $\begin{array}{c}\text { Overlap } \\
(4)\end{array}$ & $\begin{array}{c}\text { Uninsurance } \\
\text { (5) }\end{array}$ \\
\hline Simulated Eligibility & $\begin{array}{c}0.739 * * * \\
(0.149)\end{array}$ & & & & \\
\hline Eligible & & $\begin{array}{c}0.407 * * * \\
(0.146)\end{array}$ & $\begin{array}{c}-0.450^{* * * * *} \\
(0.148)\end{array}$ & $\begin{array}{c}0.015 \\
(0.061)\end{array}$ & $\begin{array}{c}0.111 \\
(0.134)\end{array}$ \\
\hline Female & $\begin{array}{c}0.063 * * * \\
(0.005)\end{array}$ & $\begin{array}{c}0.009 \\
(0.012)\end{array}$ & $\begin{array}{c}0.098 * * * \\
(0.011)\end{array}$ & $\begin{array}{l}-0.001 \\
(0.004)\end{array}$ & $\begin{array}{c}-0.070 * * * \\
(0.008)\end{array}$ \\
\hline Black & $\begin{array}{c}0.031^{* * *} \\
(0.006)\end{array}$ & $\begin{array}{c}0.093 * * * \\
(0.010)\end{array}$ & $\begin{array}{c}-0.081 * * * \\
(0.010)\end{array}$ & $\begin{array}{c}0.003 \\
(0.003)\end{array}$ & $\begin{array}{c}-0.023 * * * \\
(0.008)\end{array}$ \\
\hline Hispanic & $\begin{array}{c}0.020 \\
(0.017)\end{array}$ & $\begin{array}{c}0.034 \\
(0.028)\end{array}$ & $\begin{array}{c}-0.056^{* * * *} \\
(0.013)\end{array}$ & $\begin{array}{c}-0.013^{* * *} \\
(0.005)\end{array}$ & $\begin{array}{c}0.043 * * * \\
(0.016)\end{array}$ \\
\hline No High School & $\begin{array}{c}0.082 * * * \\
(0.008)\end{array}$ & $\begin{array}{c}0.185^{* * * *} \\
(0.015)\end{array}$ & $\begin{array}{c}-0.218^{* * *} * \\
(0.014)\end{array}$ & $\begin{array}{c}0.003 \\
(0.005)\end{array}$ & $\begin{array}{c}0.003 \\
(0.013)\end{array}$ \\
\hline High School & $\begin{array}{c}0.013 * * \\
(0.006)\end{array}$ & $\begin{array}{c}0.078 * * * \\
(0.005)\end{array}$ & $\begin{array}{c}-0.106 * * * \\
(0.006)\end{array}$ & $\begin{array}{c}0.007 * * * \\
(0.002)\end{array}$ & $\begin{array}{r}0.020^{* * *} \\
(0.005)\end{array}$ \\
\hline Married & $\begin{array}{c}-0.010 * * \\
(0.004)\end{array}$ & $\begin{array}{c}-0.196 * * * * \\
(0.006)\end{array}$ & $\begin{array}{c}0.307^{*} * * \\
(0.010)\end{array}$ & $\begin{array}{c}-0.014 * * * \\
(0.003)\end{array}$ & $\begin{array}{c}-0.060 * * * \\
(0.004)\end{array}$ \\
\hline $\begin{array}{l}\text { Mean of Dep. Variable } \\
1^{\text {st }} \text { stage F-test } \\
\text { (P-value on null) }\end{array}$ & $\begin{array}{l}0.575 \\
24.70\end{array}$ & 0.28 & 0.42 & 0.04 & 0.19 \\
\hline R-squared & 0.4755 & 0.2472 & 0.2757 & 0.0193 & 0.0688 \\
\hline
\end{tabular}

Notes: Standard errors are in parentheses and are clustered at the state level. * Represents a $10 \%$ significance level. ** Represents a 5\% significance level. *** Represents a $1 \%$ significance level. All models have 170,909 observations. All regressions are weighted using the SIPP provided person-level weight. All regressions control for panel-wave, state and year fixed effects, a state linear trend, age, age squared, a cubic in income, number of children in household, and family size. Source: Author's Calculation.

Table 8: The Extent of Crowd-out from Work Disability Population from 1996, 2001, 2004 panels of the SIPP

\begin{tabular}{lcc}
\hline \hline & No Overlap & Overlap \\
\cline { 2 - 3 } & $(1)$ & $(2)$ \\
Crowd-out rate $(\%)$ & 1.11 & 1.10 \\
$95 \%$ Confidence Interval & {$[0.262,3.899]$} & {$[0.329,2.938]$} \\
\hline \hline
\end{tabular}

Notes: Numbers in brackets are 95\% confidence intervals and these values are constructed using a clustered bootstrap with 350 repetitions. The No Overlap column estimates the extent of crowd-out without considering the population with overlapping

Journal of Health Economics, Vol. 40 (March 2015): pg. 69-82. DOI. This article is @ Elsevier and permission has been granted for this version to appear in e-Publications@Marquette. Elsevier does not grant permission for this article to be further copied/distributed or hosted elsewhere without the express permission from Elsevier. 
NOT THE PUBLISHED VERSION; this is the author's final, peer-reviewed manuscript. The published version may be accessed by following the link in the citation at the bottom of the page.

coverage. The Overlap column includes the overlapping coverage population in its calculation assuming that the change in overlap coverage represents a transition from private to public coverage.

Table 9: First-Stage for and 2SLS Estimates of Insurance Coverage Regressions Robustness of Results to Alternative Samples

\begin{tabular}{|c|c|c|c|c|c|}
\hline \multirow{4}{*}{ Dep. Var. } & \multirow{3}{*}{$\begin{array}{c}\text { First-Stage } \\
\text { Eligible } \\
\end{array}$} & \multicolumn{4}{|c|}{ 2SLS Estimates } \\
\hline & & \multicolumn{4}{|c|}{ Private } \\
\hline & & Only & Only & Overlap & Uninsured \\
\hline & (1) & $(2)$ & $(3)$ & (4) & $(5)$ \\
\hline & \multicolumn{5}{|c|}{$\begin{array}{l}\text { Panel A: Work Disability Sample from the } 1997-2008 \text { March CPS } \\
\text { (80,727 observations) }\end{array}$} \\
\hline Simulated Eligibility & $\begin{array}{c}1.074 \\
(0.092)^{* * * * *}\end{array}$ & & & & \\
\hline Eligible & & $\begin{array}{l}0.249^{*} \\
(0.150)\end{array}$ & $\begin{array}{c}-0.218^{* *} \\
(0.101)\end{array}$ & $\begin{array}{l}0.071^{*} \\
(0.043)\end{array}$ & $\begin{array}{l}0.131^{*} \\
(0.074)\end{array}$ \\
\hline $\begin{array}{l}\text { Mean of Dep. Var. } \\
1^{\text {st }} \text { stage F } \\
\text { (P-value on null) }\end{array}$ & $\begin{array}{c}0.55 \\
135.257\end{array}$ & 0.29 & 0.39 & 0.04 & 0.14 \\
\hline \multirow[t]{2}{*}{ R-squared } & 0.5310 & 0.2430 & 0.2663 & 0.0100 & 0.0340 \\
\hline & \multicolumn{5}{|c|}{$\begin{array}{l}\text { Panel B: Non-Work Disabled Sample from 1996, 2001, and } 2004 \text { SIPP panels. } \\
\qquad(1,290,995 \text { observations })\end{array}$} \\
\hline Simulated Eligibility & $\begin{array}{c}0.814 \\
(.053)^{* * * * *}\end{array}$ & & & & \\
\hline Eligible & & $\begin{array}{l}-0.037 \\
(0.036)\end{array}$ & $\begin{array}{c}0.010 \\
(0.047)\end{array}$ & $\begin{array}{l}-0.004 \\
(0.010)\end{array}$ & $\begin{array}{c}0.025 \\
(0.065)\end{array}$ \\
\hline Mean Dep. Var. & 0.342 & 0.03 & 0.78 & 0.01 & 0.18 \\
\hline $\begin{array}{l}1^{\text {st }} \text { stage } \mathrm{F} \\
\text { (P-value on null) }\end{array}$ & 235.62 & & & & \\
\hline \multirow[t]{2}{*}{ R-squared } & 0.5272 & 0.0796 & 0.2415 & 0.0167 & 0.1844 \\
\hline & \multicolumn{5}{|c|}{$\begin{array}{c}\text { Panel C: Work Disabled Sample 1996, 2001, and } 2004 \text { SIPP panels - First } \\
\text { Three Waves of Panels Only (46,623 observations) }\end{array}$} \\
\hline Simulated Eligibility & $\begin{array}{l}0.977 \\
(0.227)^{* * * *}\end{array}$ & & & & \\
\hline Eligible & & $\begin{array}{l}0.422 * * \\
(0.215)\end{array}$ & $\begin{array}{l}-0.484 \\
(0.318)\end{array}$ & $\begin{array}{l}-0.008 \\
(0.107)\end{array}$ & $\begin{array}{c}0.305 \\
(0.259)\end{array}$ \\
\hline $\begin{array}{l}\text { Mean Dep. Var. } \\
1^{\text {st }} \text { stage F } \\
\text { (P-value on null) }\end{array}$ & $\begin{array}{c}0.585 \\
18.576\end{array}$ & 0.30 & 0.42 & 0.04 & 0.19 \\
\hline R-squared & 0.4869 & 0.2615 & 0.2708 & 0.0154 & 0.0237 \\
\hline
\end{tabular}

Notes: Standard errors are in parentheses and are clustered at the state level. * Represents a $10 \%$ significance level. ** Represents a $5 \%$ significance level. *** Represents a $1 \%$ significance level. Estimates are from 2SLS regressions of four forms of health coverage (Medicaid only, Private Only, Both Medicaid and Private, and Uninsured) for different sample populations using simulated eligibility as an instrument. All columns control for state and year fixed effects, age, age squared, number of children in household, family size, female sex, black race, Hispanic origin, marital status, cubic in personal income, less than high school education, and high school diploma.

Journal of Health Economics, Vol. 40 (March 2015): pg. 69-82. DOI. This article is (C) Elsevier and permission has been granted for this version to appear in e-Publications@Marquette. Elsevier does not grant permission for this article to be further copied/distributed or hosted elsewhere without the express permission from Elsevier. 
NOT THE PUBLISHED VERSION; this is the author's final, peer-reviewed manuscript. The published version may be accessed by following the link in the citation at the bottom of the page.

Panel A: Results for this table are for the 1997-2008 March CPS surveys. Sample includes all individuals between the ages of 20 and 64 who report a work disability. The 5 states that are not uniquely identified in the SIPP are excluded from the CPS analysis. Results are weighted using the SHADAC constructed weight for CPS health insurance coverage.

Panel B: Sample includes individuals between the ages of 20 and 64 in the 1996, 2001, and 2004 panels of the SIPP who do not report a work disability. All regressions are weighted using the SIPP provided person-level weight.

Panel C: Sample includes individuals between the ages of 20 and 64 who report a work disability in the in all 3 of the first three waves of each SIPP panel. All regressions are weighted using the SIPP provided person-level weight.

Source: Author's calculation.

Table 10: Effects of Medicaid Eligibility on Insurance Coverage for Work-Disabled Individuals in the 1996, 2001, and 2004 SIPP Panels: Adjusting Insurance Coverage Measures to Account for Medicare (170,909 observations)

\begin{tabular}{|c|c|c|c|c|c|c|c|}
\hline Dependent Variable & Private Only & $\begin{array}{c}\text { Medicaid } \\
\text { Only }\end{array}$ & $\begin{array}{c}\text { Medicare } \\
\text { Only }\end{array}$ & $\begin{array}{l}\text { Medicaid- } \\
\text { Medicare }\end{array}$ & $\begin{array}{c}\text { Private- } \\
\text { Medicaid }\end{array}$ & $\begin{array}{l}\text { Private- } \\
\text { Medicare }\end{array}$ & $\begin{array}{c}\text { All } \\
\text { Three }\end{array}$ \\
\hline Eligible & $\begin{array}{c}-0.274^{* * *} \\
(0.127)\end{array}$ & $\begin{array}{c}0.239 \\
(0.160)\end{array}$ & $\begin{array}{l}-0.083 \\
(0.083)\end{array}$ & $\begin{array}{l}0.167^{*} \\
(0.080)\end{array}$ & $\begin{array}{l}-0.024 \\
(0.051)\end{array}$ & $\begin{array}{l}-0.178 \\
(0.121)\end{array}$ & $\begin{array}{c}0.039 \\
(0.038)\end{array}$ \\
\hline Mean Dep. Var. & 0.35 & 0.22 & 0.08 & 0.07 & 0.03 & 0.07 & 0.02 \\
\hline R-squared & 0.2195 & 0.1983 & 0.0895 & 0.0370 & 0.0100 & 0.0824 & 0.0013 \\
\hline
\end{tabular}

Notes: Standard errors are in parentheses and are clustered at the state level. * Represents a $10 \%$ significance level. ** Represents a $5 \%$ significance level. ${ }^{* * *}$ Represents a $1 \%$ significance level. All regressions are weighted using the SIPP provided person-level weight. Estimates are from 2SLS regressions of various forms of health coverage on Medicaid income eligibility using simulated eligibility as an instrument. Coverage forms are defined similar as in earlier tables, but now take into account Medicare coverage. Three represents coverage by all three forms of insurance (Medicaid, Private, and Medicare). All columns control for panel-wave, state and year fixed effects, a state-linear trend, age, age squared, a cubic in income, number of children in household, family size, female sex, black race, Hispanic origin, marital status, less than high school education, and high school diploma.

Source: Author's calculation. 
NOT THE PUBLISHED VERSION; this is the author's final, peer-reviewed manuscript. The published version may be accessed by following the link in the citation at the bottom of the page.

\section{Appendix: Pathways for Disabled Medicaid Eligibility}

\section{A. 1 Categorical Eligibility - SSI Recipients}

The Supplemental Security Income (SSI) Program is run by the Social Security Administration (SSA) and provides a cash supplement to the aged and disabled who have few financial resources. Individuals are eligible to receive SSI if their countable income and assets are less than the income and resource eligibility levels determined by the SSA. ${ }^{28}$ In 2012, the SSI income and resource eligibility levels for an individual were $75 \%$ of the federal poverty level (FPL) and $\$ 2,000$ respectively (Social Security Administration, 2012).

States are required to offer Medicaid to all SSI recipients unless they use a 209(b) option that allows states to employ stricter eligibility levels than SSI requirements. However, under this option, the eligibility levels cannot be any more restrictive than Medicaid eligibility levels used by the state in 1972 - when SSI was created. Eleven states used the 209(b) option in 2009. ${ }^{29}$ Each 209(b) state has at least one aspect of Medicaid eligibility that is more restrictive than federal SSI standards. The most obvious method of imposing stricter standards is through lower income and resource eligibility levels though some states choose stricter definitions of disability or countable income/assets. Standards for SSI have changed little over the time period considered in this paper. SSI/categorical eligibility is the only mandatory Medicaid pathway for the aged and disabled that all states must offer. All other pathways are at the option of the state.

\section{A.2 State Supplemental Payments (SSP)}

States may choose to offer supplementary payments to SSI recipients and also to those who do not qualify for SSI but have lower levels of income. The state supplemental payment option allows states to increase their cash assistance levels for the elderly and disabled above the federal standard. States choose the size of their supplemental payments effectively creating an income "floor" for eligible state residents. States have complete control over

\footnotetext{
${ }^{28}$ Countable income is the applicant's total income minus certain monetary disregards. There is a federally mandated disregard of $\$ 20$ dollars though some states are more generous. In addition, $\$ 65$ of earned income plus half of remaining earnings are disregarded when constructing countable income. See the SSA's "Understanding Supplemental Security Income" website at http://www.ssa.gov/ssi/text-understanding-ssi.htm for more information. 29 These states were Connecticut, Hawaii, Illinois, Indiana, Minnesota, Missouri, New Hampshire, North Dakota, Ohio, Oklahoma, and Virginia.

${ }^{29}$ These states were Connecticut, Hawaii, Illinois, Indiana, Minnesota, Missouri, New Hampshire, North Dakota, Ohio, Oklahoma, and Virginia.
}

Journal of Health Economics, Vol. 40 (March 2015): pg. 69-82. DOI. This article is @ Elsevier and permission has been granted for this version to appear in e-Publications@Marquette. Elsevier does not grant permission for this article to be further copied/distributed or hosted elsewhere without the express permission from Elsevier. 
SSP eligibility levels and can vary them by living arrangement, type of recipient (aged or disabled), and by regional differences (typically differences in the cost of living) within a state (Stone, 2002). Throughout my analysis, I use SSP levels for an individual living independently since the data only contain information for non-institutionalized individuals. The income eligibility level for the SSP pathway is roughly equal to the maximum allowance offered through SSI plus the additional SSP payments. All states, however, must use the SSI resource levels unless they are a 209(b) state. ${ }^{30}$

Individuals who receive SSP from the state but do not qualify for SSI are referred to as SSP-only recipients and are not eligible for Medicaid through the SSI pathway. ${ }^{31}$ States have the option to extend Medicaid coverage to SSP-only individuals and most states offering SSP pursue this option. In 2001, twenty-five states offered SSP-only Medicaid coverage to the qualifying individuals living independently (Bruen, 2003). Most states offer a supplement that raises an individual's income and subsequent Medicaid eligibility level just above SSI levels. Some states, however, offer large payments that can effectively raise the SSP-only Medicaid income eligibility level above the federal poverty level (Bruen, 2003). ${ }^{32}$ SSP policies have also varied little over the time period considered in this paper.

\section{A.3 Medically Needy}

A medically needy program allows individuals with high income but large amounts of medical expenses to qualify for Medicaid coverage. States with medically needy programs allow residents to subtract their medical expenses from their countable income and essentially "spend- down" to Medicaid eligibility. That is, for states with medically needy programs there is effectively no income limit on Medicaid applicants as long as an applicant incurs enough medical costs to reach the medically needy income limit. 209(b) states who do not have a medically needy program must allow individuals to spend down to eligibility. Though states may choose to offer less generous benefits packages to medically needy individuals, medically needy packages are essentially the same as those offered for income eligible recipients.

States can choose medically needy income and resource levels unique from other pathways for eligibility. Most states choose to set their medically

\footnotetext{
${ }^{30}$ In which case they use the resource level used by the 209(b) state.

${ }^{31}$ SSP-only individuals are those who have incomes higher than SSI levels, but lower than the income floor set by the state.

32 States with the maximum SSI/SSP for the independently living aged and disabled above $100 \%$ of the FPL in 2001 were Connecticut and Alaska.
}

Journal of Health Economics, Vol. 40 (March 2015): pg. 69-82. DOI. This article is (C) Elsevier and permission has been granted for this version to appear in e-Publications@Marquette. Elsevier does not grant permission for this article to be further copied/distributed or hosted elsewhere without the express permission from Elsevier. 
NOT THE PUBLISHED VERSION; this is the author's final, peer-reviewed manuscript. The published version may be accessed by following the link in the citation at the bottom of the page.

needy levels well below poverty and sometimes even below SSI standards. To qualify under the medically needy pathway, applicants get a certain time period ( 1 to 6 months depending on the state) to reduce their income by their medical expenses. If they reach the medically needy income limit after the deduction of their medical expenses then they qualify for Medicaid coverage for the rest of the period. Except for four states (Texas and South Carolina eliminated their medically needy programs in 1996 and 1993 respectively. Oklahoma and Oregon both ended their medically needy programs in 2003), all states that had a medically needy program in 1991 also had them in 2008. In 2008, 33 states had a medically needy program.

\section{A. 4 Medicaid Buy-in for the Working Disabled}

Though Medicaid does disregard certain amounts of earned income when determining eligibility, many working disabled have too much income to qualify for Medicaid coverage. This pathway allows disabled individuals to work and earn up to $250 \%$ of the federal poverty level. Unlike other Medicaid recipients, however, workers qualifying under this pathway have to pay a premium and buy-in to the Medicaid program. Premiums for the Medicaid buy-in tend to be much smaller than those available on the private market.

\section{A.5 Medicare Cost Sharing - Dual Eligibles: QMB's, SLMB's, and QI's}

Medicaid always acts as the payer of last resort allowing all other sources of payment to be exhausted before coverage. Disabled individuals who have been covered under Social Security Disability Insurance for 24 months qualify for coverage by Medicare. Medicare, however, is not a full coverage health insurance plan though its coverage is quite extensive. There are gaps within Medicare benefits (such as long-term care expenses and prescription drug costs) and it also requires premiums and copays that many low income individuals may not be able to afford.

To prevent Medicare eligible individuals from dropping their Medicare policies in favor of less expensive Medicaid coverage, Medicaid began offering coverage of Medicare premiums and copayments for individuals who qualify for both Medicare and Medicaid (dual-eligibles). For dual-eligibles, Medicaid will only cover what Medicare does not, allowing Medicare to cover many of the first order expenses.

There are three forms of dual-eligibles that qualify for different provisions through Medicaid. A Qualified Medicare Beneficiary (QMB) was established under the Medicare Catastrophic Coverage Act of 1988. QMB's receive Medicaid coverage of Medicare Part $B$ premiums, deductibles, and copayments if they qualify for Medicare Part A and have incomes less than $100 \%$ of the Federal Poverty Level. Specified Low-Income Medicare Beneficiaries (SLMB's) were established in 1993 and qualify for Medicare Part

Journal of Health Economics, Vol. 40 (March 2015): pg. 69-82. DOI. This article is (C) Elsevier and permission has been granted for this version to appear in e-Publications@Marquette. Elsevier does not grant permission for this article to be further copied/distributed or hosted elsewhere without the express permission from Elsevier. 
NOT THE PUBLISHED VERSION; this is the author's final, peer-reviewed manuscript. The published version may be accessed by following the link in the citation at the bottom of the page.

B premiums if they qualify for Medicare Part A and have incomes above $100 \%$ but less than $110 \%$ of the federal poverty level. The SLMB income limit was raised in 1995 to $120 \%$ of the FPL. The last of the dual-eligible types is a Qualifying Individual-1 (QI-1) who has incomes above $120 \%$ but below $135 \%$ of the federal poverty level. Medicaid will pay the Part B premiums for QI-1's. All Medicare cost sharing participants must have resources less than twice SSI levels.

\section{About the Author}

Kathryn L. Wagner: Department of Economics, Marquette University, College of Business Administration, David Straz Hall \#418, P.O. Box 1881 Milwaukee, WI 53201, (414)288-3409. 